\title{
Portraying an employee performance management system based on multi-criteria decision analysis
} and visual techniques

\author{
Vijay Edward Pereira \\ Department of Organisation Studies and HRM, \\ University of Portsmouth Business School, Portsmouth, England, and \\ Alessio Ishizaka \\ Department of Operations and Systems Management, University of Portsmouth Business School, \\ Portsmouth, England
}

\begin{abstract}
Purpose - Performance appraisal is one of the most critical and indispensable human resource practices for organisations. However, it generates dissatisfaction among employees as it is often viewed as complex and ineffective. The purpose of this paper is to present a new performance management system that integrates multi-criteria decision analysis (MCDA) methods - the analytic network process (ANP) and PROMETHEE - with the visual techniques of the GAIA plane and the stacked bar chart. MCDA methods allow a structured and consistent evaluation integrating qualitative and quantitative criteria.

Design/methodology/approach - The authors developed a structured and transparent performance management system. It is based on the MCDA methods PROMETHEE and ANP. It also incorporates the visual techniques: GAIA and stacked bar chart. Feedback for trainings and developments can precisely be formulated.
\end{abstract}

Findings - Visual techniques permit clear identification and quantification, for each employee, of the areas that need improvement through training and development, which contributes to the resource-based view of organisations. A real case study has been portrayed to show the added value of the MCDA methods and the visual techniques in employee performance management.

Originality/value - The paper describes a new employee performance system adopted in an organisation. The multi-criteria analysis transparently combines qualitative and quantitative decision criteria into a 
holistic and transparent evaluation. The visual techniques permit us to gain a deep insight into the employees' skills profile and capture fine details where individuals perform or underperform. Keywords: MCDA, ANP, PROMETHEE, Visual techniques, Personnel evaluation, Performance management

\section{Introduction}

Companies need to measure and improve their performances in all business areas if they want to remain competitive. Employees' performance is not an exception, especially as employees are often considered the most important and complex asset of an organisation (Coff 1997, Vaiman and Vance 2008). Performance appraisals evaluate the job performance of employees and the results are then communicated to and discussed with the relevant employees. It measures how well employees perform job-relevant tasks and further helps in distinguishing the more efficient employees. According to Workman (2009), managers are not only “....involved in the gathering of information about employees such as their performance measurements compared to their objectives and other work-related activities", but they also "monitor" employees' attitudes, organisational behaviour and absenteeism. Performance evaluations are thus the basis for determining the development and training needs of employees.

The motivation for conducting our study is thus. Reviewing and evaluating the performance of employees is an important task as critical decisions for employees, such as those relating to promotions, pay rises, rewards, retention, training needs etc., rely on the accurate assessment of employees. Many researchers, such as Cho and Lee (2012) and Liu et al. (2007), have also highlighted that performance management leads to better organisational performance. Paradoxically, it is claimed that managers often trivialise the process or even totally avoid it (Pettijohn et al. 2001). The results of a US survey (Watson Wyatt Worldwide 2004) of 1,200 employees, in which $90 \%$ of the respondents participated in a performance management programme, showed that only $30 \%$ believed the process helped them to improve their performance. Furthermore, less than $40 \%$ said the system established clear performance 
goals or generated honest feedback. It is therefore not surprising that employees see it as a bureaucratic process and a waste of time that does not add much value. Few managerial tasks are viewed more negatively or performed as unevenly as performance review or appraisal (Aguinis et al. 2011). Often, performance appraisals are months overdue (Heathfield 2007), at times leading to a lapse in trust and leadership ability (Reinke 2003). This contradiction between the notional high benefits and neglect in practice may be attributed to managers being ill-equipped to conduct effective appraisals.

It is also argued that most performance appraisals are a 'managerial prerogative' (see arguments made by Biron et al. (2011)) and hence is a 'behavioural performance appraisal' (Snell and Youndt 1995). The drawback here is that it could be biased and unfair. Others argue that there are aspects of 'employee initiatives', where, certain behaviours can lead to increased performance (e.g. Wood and Marshall 2008). It is understood that robust selection and training initiatives by organisations helps to socialise employees, ensuring that they have the requisite abilities required by organisations (e.g. Selvarajan and Cloninger 2012). However, here too performance appraisals cannot be solely based on 'employee initiative'. Further, there are 'mutually agreed' performance parameters that lead to certain agreed performance behaviours and outcomes (e.g. Gruman and Saks 2011), but again these cannot be assessed in isolation. The key here is to have a combination of criterion, which this study aims to portray through a case study.

In addition, it is argued that "...the use of eHR software in people management gives a new momentum and increased dominance to key Western-originated practices, such as HR based performance management" (Alcaraz et al. 2012, p. 106). In addition, "cultural" differences in managing people in the subsidiaries of global organisations worldwide can be a challenge in settings such as global software organizations, which "represent one kind of workplace setting within the new economy" (D'Mello and Eriksen 2010, p. 81). Such "new economy" organisations face fresh challenges, as for example in call centres where the “...'gaze' of the electronic boards displaying their unceasing demands on staff combined with tele-computing and the automatic distribution of calls (ACD) ensures that backlogs are always driving performance" (Alferoff and Knights 2008, p. 31). 
It is therefore important to design and implement a transparent, unbiased, structured and effective performance management method. Responding to this contemporary and critical challenge, this paper introduces a new transparent and structured employee performance appraisal method based on the combination of two multi-criteria decision analysis (MCDA) methods, PROMETHEE (Brans 1982, Brans and Vincke 1985) and the analytic network process (ANP) (Saaty 2001), complemented with visual techniques (Nemery et al. 2012). This novel method aims to define the evaluation criteria clearly, comparing and evaluating employees' performances, which would lead to a transparent, structured and competitive appraisal method. Employees' strengths and weaknesses can thus be detected easily and justified using visual techniques. Therefore, specific recommendations for improvements can be formulated. The main advantage of PROMEHTEE is the setting of thresholds, which means that above them the score does not contribute anymore to their overall performance appraisal. This particular feature permits to avoid staff to strive to maximise their score on the considered criteria by concentring their time and efforts and neglecting tasks that do not contribute.

The structure of the paper is as follows. In section 2, we assess the importance of performance management by reviewing the extant literature. In section 3, we describe the MCDA evaluation method and section 4 is devoted to the case study. Finally, in section 5 we provide conclusions and recommend future research directions.

\section{Literature review}

A structured, consistent and transparent appraisal enhances organisational commitment and organisational citizenship behaviour (Narcisse and Harcourt 2008, Organ 1988). In contrast, an inferior appraisal method, in which employees and managers disagree about their contribution, can create conflict (Heathfield 2007) and even lead to negative consequences, such as theft, vandalism, intentional idleness, absenteeism (Sania Zaheer 2011) and intention to resign (Brown et al. 2008). Poor appraisals tend to 
avoid differentiation. The majority of the employees are wrongly ranked highly to avoid disappointment, unhappiness (Heathfield 2007), inter-employee jealousy, hostility (Law 2007) and the manager's discomfort in providing negative feedback (Chen et al. 2007). A poor appraisal method also prevents any true, transparent, structured, and honest, value adding development or improvement as everyone is already "artificially" excellent. At an organisational level, performance management ensures that employees' performances and skills are aligned with the strategic goals of the company. A comprehensive assessment can define whether the organisation has the necessary capacities in house (Merritt 2007). It also supports the implementation of strategic changes (Amaratunga and Baldry 2002) and fosters good workplace harmony (Heathfield 2007).

A detailed review of the literature on performance appraisals reveal four main characteristics that lead to certain appraisal criterion. These are position characteristics, organisation characteristics, personal characteristics, and task and target characteristics. The following table 1 defines and details these against the literature.

\begin{tabular}{|c|c|c|}
\hline $\begin{array}{c}\text { Main characteristics and } \\
\text { criteria of performance } \\
\text { appraisal }\end{array}$ & $\begin{array}{c}\text { Sub-characteristics and criteria } \\
\text { of performance appraisal }\end{array}$ & References \\
\hline $\begin{array}{l}\text { Position characteristics: } \\
\text { Defined as characteristics related } \\
\text { to the position held. The person } \\
\text { is assessed according to the } \\
\text { position held. }\end{array}$ & $\begin{array}{l}\text { Supervisory, managerial, } \\
\text { leadership, customer focus, } \\
\text { working relationships, initiatives } \\
\text { etc. } \\
\text { Because this is managerial } \\
\text { prerogative, this is mainly } \\
\text { conducted by managers. This } \\
\text { could be included in } 360 \text { degree } \\
\text { or goal setting. }\end{array}$ & $\begin{array}{l}\text { (Landy and Farr 1980, Colquitt et } \\
\text { al. 2007, Armstrong and Taylor } \\
\text { 2014, Prowse and Prowse 2009, } \\
\text { Beausaert et al. 2011, Biron et al. } \\
\text { 2011, Obisi 2011, McCarthy and } \\
\text { Garavan 2001, McCarthy and } \\
\text { Garavan 1999) }\end{array}$ \\
\hline $\begin{array}{l}\text { This is a 'managerial } \\
\text { prerogative'. }\end{array}$ & & \\
\hline $\begin{array}{l}\text { Defined mainly as the person- } \\
\text { organisation fit. Person here is }\end{array}$ & $\begin{array}{l}\text { Fit to organisational culture, fit to } \\
\text { business/sector/industry, fit to } \\
\text { business environment, etc. } \\
\text { Because this is managerial } \\
\text { prerogative, this is mainly }\end{array}$ & $\begin{array}{l}\text { (Landy and Farr 1980, Salanova } \\
\text { et al. 2005, Armstrong and } \\
\text { Taylor 2014, Prowse and Prowse } \\
\text { 2009, Beausaert et al. 2011, } \\
\text { Biron et al. 2011, Obisi 2011, }\end{array}$ \\
\hline
\end{tabular}




\begin{tabular}{|c|c|c|}
\hline $\begin{array}{l}\text { assessed to the closer fit. } \\
\text { This is also a 'managerial } \\
\text { prerogative'. }\end{array}$ & $\begin{array}{l}\text { conducted by managers. This } \\
\text { could also be included in } 360 \\
\text { degree or goal setting. }\end{array}$ & $\begin{array}{l}\text { McCarthy and Garavan 1999, } \\
\text { McCarthy and Garavan 2001) }\end{array}$ \\
\hline $\begin{array}{l}\text { Defined as mainly the personality } \\
\text { or personal traits required for the } \\
\text { assessed work. } \\
\text { This is based on the 'employee } \\
\text { initiation', linked to their } \\
\text { personality traits and personal } \\
\text { attributes. }\end{array}$ & $\begin{array}{l}\text { Organisational citizenship } \\
\text { behaviour (OCB), self- } \\
\text { development, flexibility, number } \\
\text { of projects, work travel, } \\
\text { overtime, etc. } \\
\text { This could be conducted by } \\
\text { managers or be self-reports. This } \\
\text { could also be included in } 360 \\
\text { degree goal setting. }\end{array}$ & $\begin{array}{l}\text { (Barrick and Mount 1991, Tett } \\
\text { and Burnett 2003, Prowse and } \\
\text { Prowse 2009, Armstrong and } \\
\text { Taylor 2014, de Waal 2010, } \\
\text { Eisenhardt 1985, Selvarajan and } \\
\text { Cloninger 2012, Snell 1992, } \\
\text { Snell and Youndt 1995, } \\
\text { McCarthy and Garavan 1999, } \\
\text { McCarthy and Garavan 2001, } \\
\text { Organ 1988) }\end{array}$ \\
\hline $\begin{array}{l}\text { Defined as task and targets set by } \\
\text { the organisation. Assessment } \\
\text { here would be against these set } \\
\text { tasks and targets. } \\
\text { This is mutually (management } \\
\text { and employee) set performance } \\
\text { targets. }\end{array}$ & $\begin{array}{l}\text { These could be sales or output } \\
\text { targets, tasks defined by the } \\
\text { organisation, absenteeism, } \\
\text { loyalty, integrity, etc. } \\
\text { This could be conducted by } \\
\text { managers or be self-reports. This } \\
\text { could be included in } 360 \text { degree } \\
\text { or goal setting. }\end{array}$ & $\begin{array}{l}\text { (Locke et al. 1981, Rotundo and } \\
\text { Sackett 2002, Armstrong and } \\
\text { Taylor 2014, Prowse and Prowse } \\
\text { 2009, Gruman and Saks 2011, } \\
\text { Skule 2004, Ubeda and Santos } \\
\text { 2007, Ng and Feldman 2010, } \\
\text { McCarthy and Garavan 1999, } \\
\text { McCarthy and Garavan 2001) }\end{array}$ \\
\hline
\end{tabular}

Table 1 - Table portraying the extant literature on the characteristics and criteria of performance appraisal.

In terms of the types of performance appraisals conducted by organisations, ' $360^{\circ}$ feedback is a performance appraisal approach that relies on the input an employee's superiors, colleagues, subordinates, sometimes customers, suppliers and or spouses.' (McCarthy and Garavan 2001, p.6). However although studies suggests that $360^{\circ}$ feedback leads to increased performance, some studies suggest that receiving feedback from peers would be poorer quality and less valid. It is also suggested that $360^{\circ}$ feedback is 
time consuming and may not result in an increase in employee performance that an annual appraisal could achieve (Fletcher 2008, McCarthy and Garavan 1999). Although this suggests that in some organisations the $360^{\circ}$ feedback method does not improve the overall commitment and performance, Rai and Singh (2013) argue that companies who adopt this method of feedback are more likely to have employees who perform better than employees in a company who do not support this method.

A further feedback method to performance appraisals is goal setting. Goal setting is argued to be one of the most effective performance appraisal types that contribute to an increase in performance and motivation (Kuvaas 2011). Stansfield and Longenecker (2006) suggest that supplying employees with goals in the performance appraisal process increase performance by allowing them to have something to believe in and work towards. They also suggest that goals give managers clear objectives to evaluate their employees against. Although many researchers suggest that this method of feedback is successful, Schweitzer et al. (2004) argue that goal setting does not increase employee performance if the employee does not adopt the goal or if the goal is too simple. These researchers explored the role of goal setting, wherein they found that in some cases setting goals in performance appraisals led to unethical behaviour. It is also argued that setting goals is only appropriate when the goals are hard as they are more motivating than low and easy goals (Locke and Latham 2006). Similarly Schweitzer et al. (2004) suggest that the goals must be significant to the employee as they must be achievable in context and difficult enough to challenge the employee.

Thus the extant literature above does not specifically issue guidelines for conducting a performance appraisal, though useful inferences can be drawn from the literature on behavioural change. However, the developmental function of appraisal, where it is increasingly becoming a key performance criterion in itself, has not been integrated with the career management policies and practices in organisations. According to Borman (1991) there has been a lot of focus on the development of valid and reliable predictors, rather than construct-valid criterion measures. He argues that a criterion should reflect those behaviours and outcomes at work that competent observers (those responsible for performance appraisals) 
can agree constitute necessary standards of excellence to be achieved. In other words a set of performance criteria should cover all important performance requirements of the assessed job. Thus, performance appraisal criteria tends to be almost entirely context-dependent, measured using 'whatever is available' (see arguments made by Guion 1991). He comes up with objective performance criteria that should include turnover, absenteeism, production rates/sales, work samples and tracking performance.

In this study the authors undertook a three stage process to determine the performance appraisal criteria (see figure 1 below). First, an in-depth literature review was done to design a set of criteria for the organisation to choose from (see table 1 above). This was a priori. Second, the representatives i.e. management of the organisation (including personnel/HR) were consulted and the criteria finalised. Third, the criteria also took into consideration the culture and tradition of the industry/sector as well as the organisation. Six performance management criteria were found to be relevant to the company. These are categorised as comprising a mix of managerial prerogative, mutuality, and employee initiative (two criteria apiece). These are discussed under section 4.2 problem modelling.

In summary, an effective, structured, consistent and transparent performance management method has a positive impact on individuals, teams and the organisation, resulting in valuable and rare resources and hence a competitive advantage for firms. Employee performance measurement practices and methods are multi-dimensional and complex. Therefore, MCDA can support and capture this activity in a structured and constructive way. In addition, the use of MCDA methods and visual techniques can aid in developing greater understanding of and communicating the strengths and weaknesses of each employee, as well as the organisation's collective skills. The next section addresses in detail the proposed MCDA and visual techniques. 


\section{MCDA performance management method}

\subsection{MCDA method}

Multi-criteria decision making methods are widely employed as is evident from the reviews of various applications, for example TOPSIS (Behzadian et al. 2012), PROMETHEE (Behzadian et al. 2010) and AHP (Forman and Gass 2001, Ho 2008, Kumar and Vaidya 2006, Liberatore and Nydick 2008, Omkarprasad and Sushil 2006, Sipahi and Timor 2010). However, their application in the field of human resources management has been limited. AHP has previously been applied in human resources recruitment (Saaty et al. 2007). Fuzzy AHP has been utilised to prioritise human capital measurement indicators (Bozbura et al. 2007) and undertake employees' performance appraisal (Manoharan et al. 2011). MacBeth has been used to assess the performance of civil servants (Ensslin et al. 2000). AHP and cluster analysis have been combined for the evaluation of planning processes (Frezatti et al. 2011). AHP has also been used with the balanced scorecard to assess organisational performances (Bentes et al. 2012).

AHP and Macbeth provide good and justifiable results; however, they are based on pairwise comparisons, which render them difficult to use with a high number of alternatives. For example, in our case study (section 4), in which 111 employees are assessed, we would require $\left(111^{2}-111\right) / 2=6105$ comparisons for each criterion. Therefore, for our study, we have decided to use a pairwise-based method only for the evaluation of the criteria and to use PROMETHEE for the appraisal of the performances. An AHP-PROMETHEE combination has already been proposed in previous research (Bogdanovic et al. 2012, Brucker et al. 2004, Gervásio and Simões da Silva 2012, Herva and Roca 2013, Macharis et al. 2004, Turcksin et al. 2011, Venkata Rao and Patel 2010, Venkatesan and Kumanan 2012, Wang and Yang 2007, Yang and Deuse 2012), albeit not in the context of employee performance appraisals. When dependencies between criteria exist, ANP is used. Recently, ANP has also been combined with PROMETHEE (Hamzeh et al. 2015, Kilic et al. 2015, Govindan et al. 2014, Kabak and Dağdeviren 2014, Peng and Xiao 2013). This hybrid method will also be used in this this paper. Studies (Millet 1997, Whitaker 2007) have found that a pairwise method is more precise than a direct evaluation (e.g. using a 
scale 1 to 5), therefore ANP is used for the weights. ANP is tedious for a large number of alternatives, therefore we prefer PROMETHEE to evaluate the alternatives. PROMETHEE (Brans 1982, Brans and Vincke 1985) requires only a few parameters. It is easy to explain to non-technical persons, in our case human resource managers, and for them to use and user-friendly software is available (Gilliams et al. 2005). It does not need the definition of technical parameters as in ELECTRE. A normalisation of the scores in not needed and therefore the evaluation of each criterion can be expressed by its own units. Thus, it overcomes the drawback that ranking depends on the normalisation method selected (Ishizaka and Nemery 2011, Tofallis 2008). The decision maker needs to define a preference function that is generally characterised only by an indifference and preference threshold (Ishizaka and Nemery 2013, Nemery et al. 2012). These thresholds are important to avoid over-emphasising criteria. For example, by setting a preference threshold at 7 days of overtime, any additional day would not count toward a better appraisal. This ensures that the work-life balance of the employee is not affected. Similarly, an indifference threshold of two days means that an employee needs to work at least two days to have his extra time counted in his appraisal.

Several version of PROMETHEE exists. PROMETHEE I provides only an ordinal ranking (i.e. no score), where incomparability is possible. PROMETHEE II gives a complete cardinal ranking. PROMETHEE III allows detecting proximities between net flow values but requires an additional parameter $\alpha$. With the visual representations GAIA, it is possible to directly appreciate the proximities between the flow values. Therefore, PROMETHEE III is not needed. PROMETHEE IV is PROMETHEE II followed by a mathematical programming for an optimal resource allocation. This is not the purpose of our paper. By consequence, the most appropriate version for our study is PROMETHEE II.

It is to note that PROMETHEE may suffer from rank reversal (De Keyser and Peeters 1996), as any other MCDA method based on pairwise comparisons (Wang and Luo 2009). However, it has been proved 
that rank reversal may affect only very close actions (Mareschal et al. 2008) and therefore they can be neglected as in practice they can be considered as the same evaluation.

This hybrid method is complemented with two descriptive visual methods, GAIA and stacked bar charts.

\subsection{GAIA}

The graphical representation of actions evaluated on two criteria can be seen on a plane of two axis. An evaluation with three criteria can be seen on a space of three dimensions. If more criteria are considered, then the representation of four or more dimensions cannot be seen as we are in a hyperspace.

If we still want to represent graphically several criteria (axis) on a plane, we need to do a projection of the hyperspace into this plane. The projection needs to be done on the right angle in order to preserve the maximum information projected. The mathematical method that allows finding the right projection is called principal component analysis (Brans and Mareschal 1994). Only the end result of the projection is relevant for the employee appraisal because it allows representing the full picture of the appraised components.

The GAIA plane is a descriptive tool that represents all components of the problem on a plane. It is therefore an important complementary tool of PROMETHEE, which represents only the final results. It facilitates the decision process as easy conclusions can be drawn visually. Near actions on the plane will often have very similar rows in the variance-covariance matrix $\Phi$. The decision maker can thus easily identify actions with similar or opposite performances. Moreover, the decision maker can compare criteria as their position on the plane is an indication of their conflicting or correlated behaviour. Their length represents the distinguishing power between actions. A wash criterion has a short arrow; a discriminating criterion has a long arrow. 


\section{Organisational context of case study: Gamma}

\subsection{Company background}

The case study organisation, "Gamma", is a US-owned and headquartered business process outsourcing (BPO) services provider focused on mid-market companies. The company supports various business processes across the entire outsourcing client organisations. It has operations at several subsidiary locations in India. Gamma initially started its BPO business in 2004. Of these locations in India, it has 112 associates in Suratkal, 150 in Pimpri, 12 in Mumbai and 18 in Bangalore. The data for this study were collected at the Suratkal operation.

We found that the performance management strategy of Gamma included reward strategies that were directly linked to monthly and annual performance, shadowing, internal training, leadership development, mentoring and role modelling. This is discussed in greater detail in section 4.2.

\subsection{Problem modelling}

The authors acted as independent consultants in constructing the performance model together with the senior managers. A literature review was undertaken by the authors and the performance management criteria identified were discussed with the senior managers. Six performance management criteria were found to be relevant to the company. We have thus come up with this list of criteria through the following process:

1. We undertook an in-depth literature review to come up in designing a set of criteria for the organisation to choose from. This was a priori (see table 1).

2. The representatives i.e. management of the organisation (including personnel/HR) were consulted and the criteria finalised.

3. Sub-Criteria were grouped and a upper criteria were defined.

4. Lastly the criteria also took into consideration the culture and tradition of the industry/sector as well as the organisation. 
These are categorised as comprising a mix of managerial prerogative, mutuality, and employee initiative (two criteria apiece) and are defined and discussed in detail below.

First, it is argued that employee "performance management" is crucial but it is still a "managerial prerogative" to choose how employees' performances are appraised, analysed and managed (see e.g. Beausaert et al. 2011, Biron et al. 2011, Obisi 2011). This was evident as the case study organisation's responsibilities are standardised and imposed top-down with an overriding concern for procedures and methods. Employees are thus accountable for their actions, regardless of the results. Thus the expectations and desired behaviours are already communicated and set by the management, against which employees are assessed, through the formalised performance appraisal method. Thus results are purely based on set and expected performance criteria. Appraisals are based on supervisor observation of behaviour and feedback is used as a remedial tool (for employee performance research in different cultural contexts, see e.g.Eckert et al. 2009). In effect, this method eliminates vagueness and increases predictability by formalising the performance process. By attempting to regulate actions, this approach to performance management focuses on issues such as trust, transparency, structure, reliability and efficiency (e.g. Rai and Singh 2013). This method also remains effective as long as the task environment stays stable and predictable over time. Thus, when the behaviour of the employee is observed, a behaviour-based contract is optimal because the employee's behaviours are the purchased commodity, i.e. employees are compensated and rewarded for better "performance". This is the simple case of "complete" information. In the case of "incomplete" information, the employer can purchase information concerning the employee's behaviours and reward those behaviours. Research shows that the use of this approach relates positively to the completeness of information on cause-effect relations (see e.g. Snell and Youndt 1995). When it comes to performance, human resource management based on "behaviour control" (Eisenhardt 1985, Snell 1992) is positively related to firm performance when knowledge of cause-effect relations is complete. Two aspects of the case study organisation that could be linked to this category are "working relationships" and "initiatives". These were chosen after consultation with the senior management of the 
organisation. "Working relations" is defined as subordinate-supervisor/manager relations, peer-peer relations and employee-client relations. Similarly, "initiatives" is defined as the actions, behaviours and attitude of employees who take the initiative at work, e.g. those that need minimal supervision and take decisions when required (think on their feet). These two areas can also be linked to what Snell and Youndt (1995) call "behavioural performance appraisal”. Thus, behaviour here means observable activity that can be assessed. Further, attitude here means the established ways of responding to people and situations based on formalised beliefs, values etc., of the organisation and assessed under 'initiatives', as they are person oriented.

Second, in terms of mutually set performance targets, the management in the case study organisation undertook subordinate performance appraisals based on the results they achieved and monetary rewards were closely linked to employee performance outcomes. Examples of similar practices have been observed in other studies (e.g. Gruman and Saks 2011, Skule 2004, Ubeda and Santos 2007). Linking personal interests with the achievement of organisational targets is an approach to performance that gives individuals discretion over the processes they use, but still provides incentives for outcomes that benefit the firm (e.g. Kerr 1985). This can be linked to the employment relations literature, subscribing to the "unitarist" perspective (the general philosophy that every workplace is an integrated and harmonious entity that exists for a common purpose) in contrast to the "pluralist" perspective (the general philosophy that an enterprise contains people with a variety of different interests, aims and aspirations) (Williams and Adam-Smith 2010). Hence, within the pluralist perspective, 'mutuality' in the case study organisation was gained as both employee and the organisation benefited with common goals. Moreover, because this industry suffers from high levels of staff turnover and absenteeism, the employees in the case study organisation were assessed on their 'seniority' (loyalty) and levels of absenteeism. Thus, in the context of the case study organisation, mutuality tended to apply more when standards of desirability were mutually accepted, clear and transparent. This was made clear at different stages in their careers to all employees within the organisation. Theoretically too, as long as the firm has very clear, acceptable objectives, then a 
mutuality orientation towards performance management may elicit acceptable performance (Kerr 1985, Snell and Youndt 1995). Here, two dimensions/criteria, namely seniority and absenteeism, were argued to be relevant (e.g. Ng and Feldman 2010). This was also confirmed by the senior management of the organisation. Seniority was defined as the number of years the employee had spent in the organisation and absenteeism was the number of days in the year the employee did not attend work, over and above the regular stipulated leave. The stipulated leave for the organisation was 15 days per annum.

Third, in terms of employee initiatives, certain behaviours can lead to increased performance (e.g. Wood and Marshall 2008). It is argued that rigorous selection and training helps to socialise employees, ensuring that they have the requisite abilities, as well as understanding and internalising the values and goals of the organisation (e.g. de Waal 2010, Eisenhardt 1985, Selvarajan and Cloninger 2012, Snell 1992). It is also argued that this needs to be followed up with rigorous performance management. In this way employees are likely to act in the interest of the firm on their own initiative. This leads to the creation of goal congruence among the organisation's members by searching for and selecting people who fit the needs of the firm and will also lead to a homogeneous workforce (Snell and Youndt 1995). In addition, this development of "fit" goes further when deciding on training and the processes involved within the performance management/appraisal method and strategies. Thus, when the approach to performance management is based on employee initiative, it is envisaged that performance is higher. In the context of the case study organisation, the advantage of partly resorting to employee initiative in the context of performance management helped in preventing performance problems. The case study organisation's presumption here was that careful staffing, training and performance management practices prevented deficiencies that might be impossible to remedy later. Furthermore, this strategy may lead to better performance when standards are ambiguous, as was found to be with the case study organisation. Under this category the choices for dimensions/criteria were "self-development" and "flexibility". "Selfdevelopment" was defined as the initiative of employees to develop knowledge, skills and attitudes for themselves (their career) that would be beneficial either directly or indirectly to the organisation. This 
could be initiated by the organisation or self-initiated. "Flexibility" was defined as the ability of employees to change according to organisational circumstances. Under Flexibility were grouped three sub-criteria, namely number of projects, work travel and overtime. "Number of projects" means the number of projects employees deal with and opt to work on. "Work travel" is defined here as the willingness to travel and number of times they actually travelled for work-related matters. Finally, overtime is defined here as the willingness to do overtime and actual number of extra hours (over and above the stipulated eight hours a day) worked by each employee per annum. The case study organisation had similar options for both these areas, i.e. "self-development" and "flexibility". These two dimensions/criteria can be validated through Snell and Youndt (1995) assertion (in the context of employee initiatives) that “... executives can expect actions consistent with the interests of the firm without having to spell out the specific behavioural sequences required of individuals" (p. 716).

In the context of this study, the six dimensions/criteria discussed above can be integrated in a multicriteria problem structuring exercise. As in any problem structuring exercise, the model must be broken down into three basic components: goal, criteria (and optionally sub-criteria) and alternatives. The goal is given by the problem statement: in our case, the need for a transparent and structured employee performance evaluation method. The criteria are defined above and are represented by the six dimensions/criteria (see Fig. 1). In terms of generalisability, other criteria can be added or withdrawn according to the particular specificity and uniqueness of the company. The methodological framework described here is independent of these specificities and can be applied to all models. 


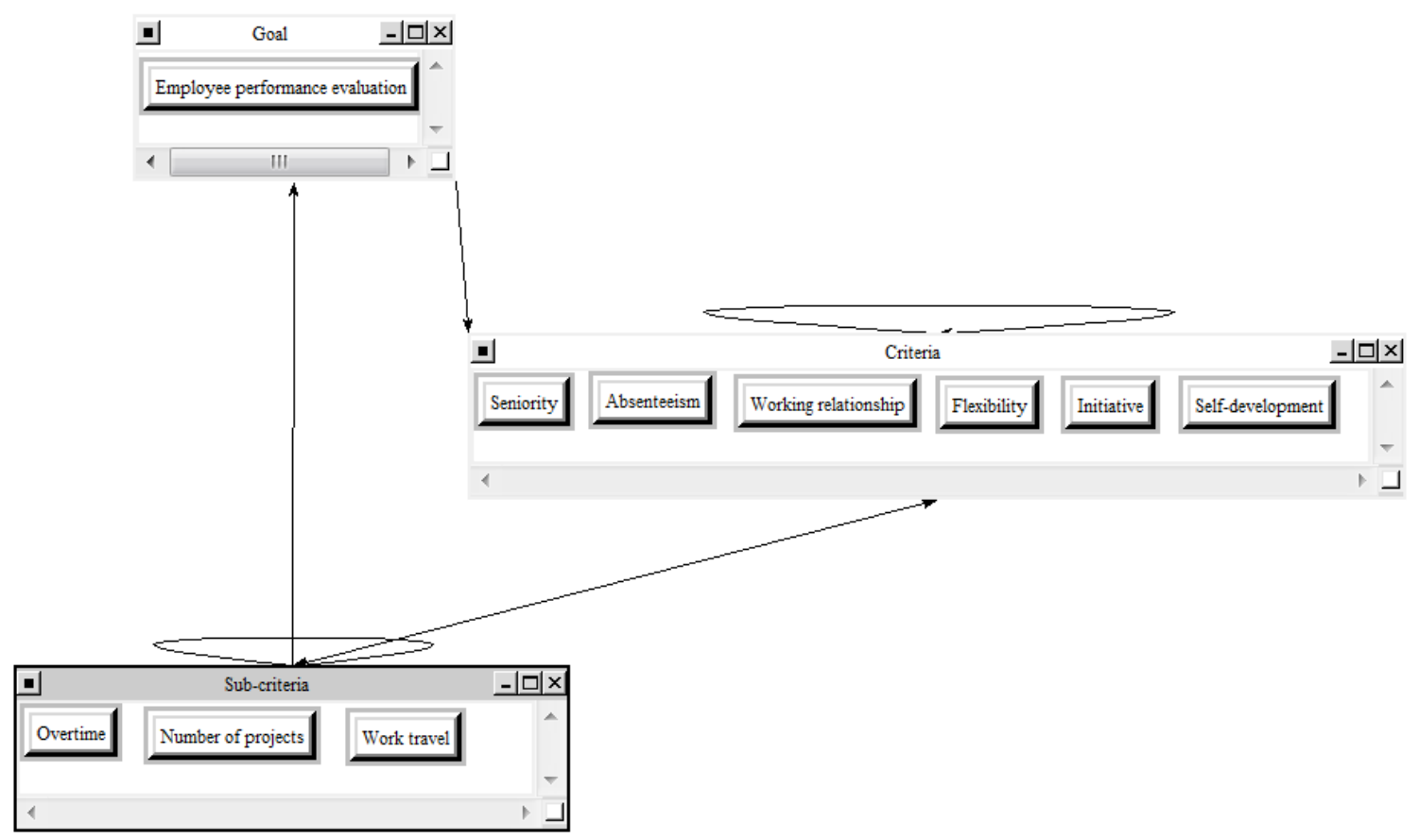

Figure 1. Criteria network for employee performance evaluation

\subsection{Influence matrix}

As the criteria are not independent, the case study organisation managers marked the dependencies in table 2.

Please note that the left column influences top row. Hence, seniority does not influence any of the criteria on the top row. Absenteeism is found to influence the majority of criteria apart from seniority. Working relationships does not influence any criteria other than work travel. Flexibility influences overtime, number of projects and work travel. Initiative influences most criteria other than seniority, absenteeism and work relationship. Self-development only influences flexibility, initiative and number of projects. Overtime influence absenteeism, flexibility, initiative and number of projects. Number of projects influences seniority, flexibility, initiative and work travel. Lastly, work travel influences flexibility, initiative, overtime and number of projects. 
Table 2 Influence matrix

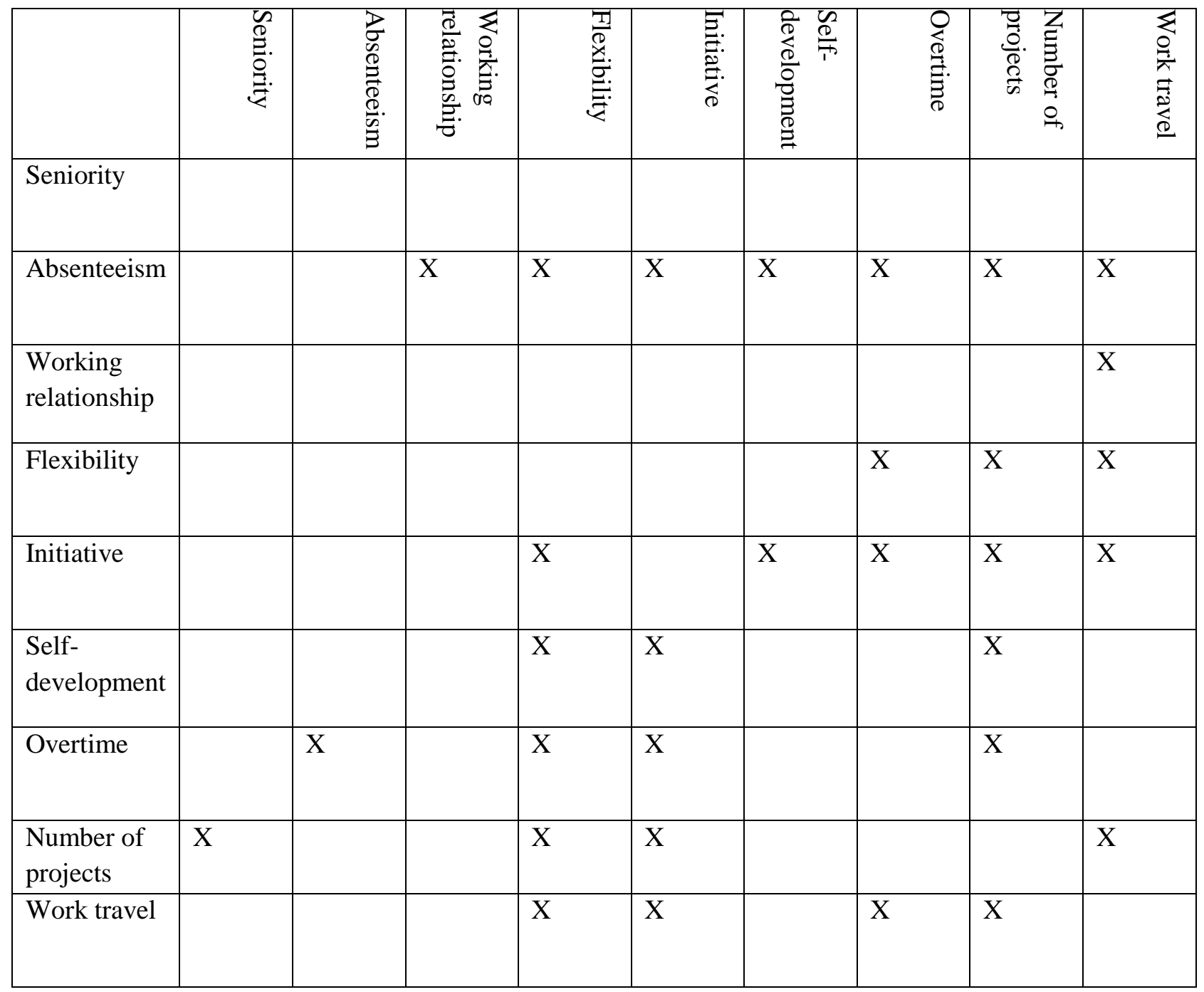

\subsection{Criteria}

To evaluate the importance of the criteria described in section 4.2, the ANP method was used. A

pairwise questionnaire was sent to the human resources manager of the case study organisation, Gamma.

Figure 2 shows the data related to the completed questionnaires. 


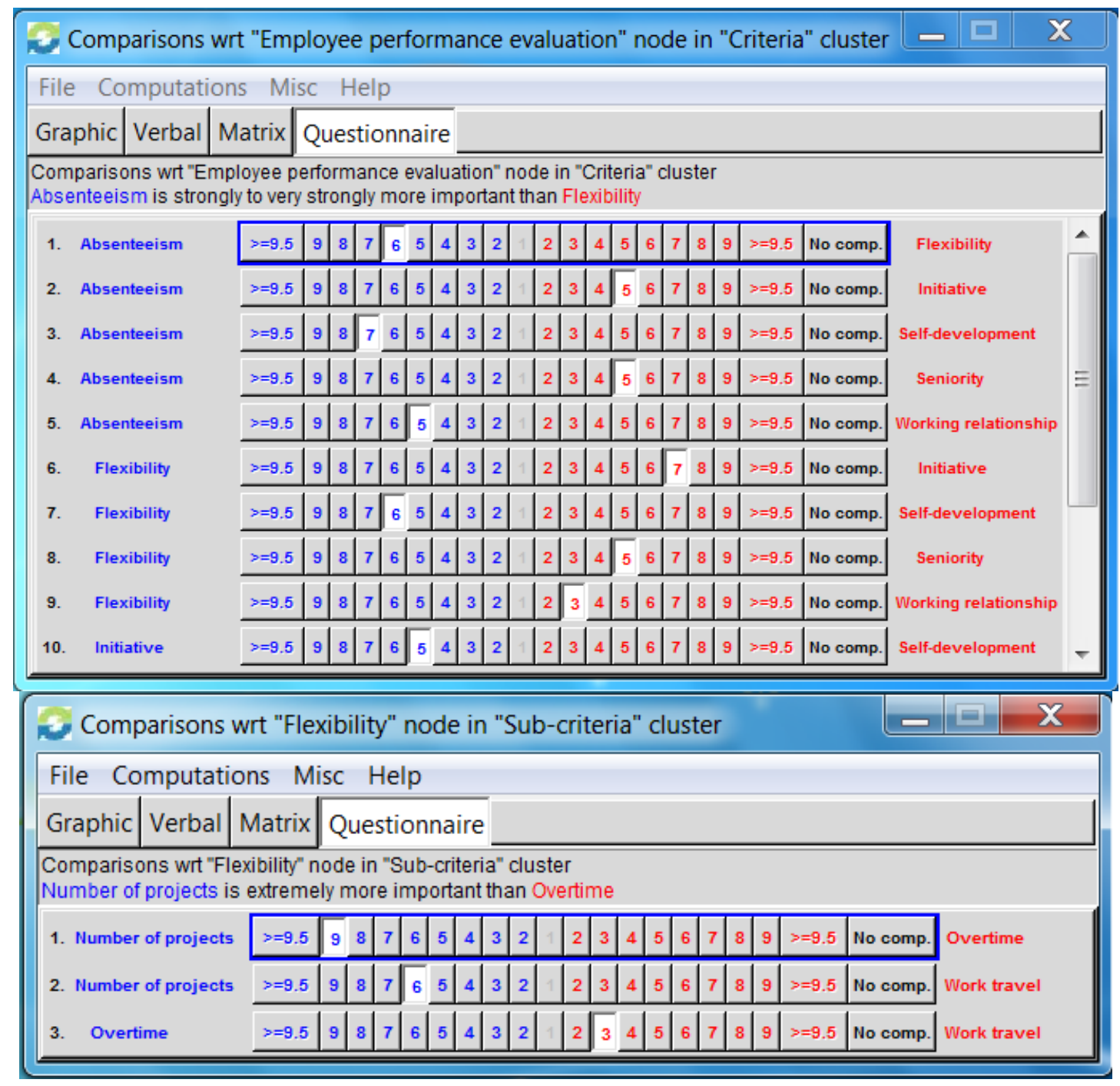

Figure 2. Questionnaire for evaluating performance criteria

However, we need also to take into account the dependencies (section 4.3). Therefore, further questions have been asked to the human resources manager (Figure 3). For example, if we evaluate number of projects and overtime knowing that absenteeism belongs also among the criteria, which is one is the most important. The HR manager believes that the number of projects is stronger dependent with absenteeism than overtime. Therefore in order to not overweight the number of projects, a stronger preference (6 times) is given to overtime. 
File Computations Misc Help

\begin{tabular}{l|l|l|l|l|} 
Graphic & Verbal & Matrix & Questionnaire \\
\hline
\end{tabular}

Comparisons wrt "Initiative" node in "Sub-criteria" cluster

Number of projects is equally as important as Overtime

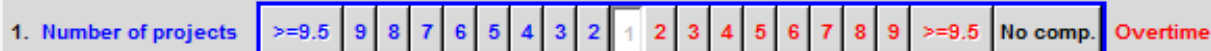

2. Number of projects \begin{tabular}{rl|l|l|l|l|l|l|l|l|l|l|l|l|l|l|l|l|l|l|}
$s=9.5$ & 9 & 8 & 7 & 6 & 5 & 4 & 3 & 2 & & 2 & 3 & 4 & 5 & 6 & 7 & 8 & 9 & $s=9.5$ & No comp. Work travel
\end{tabular}

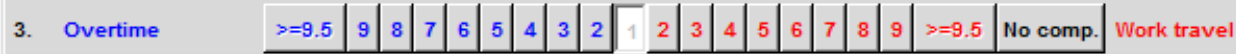

\section{\begin{tabular}{|l|l|l|l|} 
Comparisons wrt "Self-development" node in "Criteria" cluster & - & & $\mathbf{X}$ \\
\hline
\end{tabular}}

File Computations Misc Help

\begin{tabular}{l|l|l|l|l|}
\hline Graphic & Verbal & Matrix & Questionnaire
\end{tabular}

Comparisons wrt "Self-development" node in "Criteria" cluster

Flexibility is strongly more important than Initiative

1. Flexibility \begin{tabular}{|l|l|l|l|l|l|l|l|l|l|l|l|l|l|l|l|l|l|l|l|}
\hline$>=9.5$ & 9 & 8 & 7 & 6 & 5 & 4 & 3 & 2 & & 2 & 3 & 4 & 5 & 6 & 7 & 8 & 9 & $>=9.5$ & No comp. Initiative
\end{tabular}

\section{Comparisons wrt "Work travel" node in "Sub-criteria" cluster}

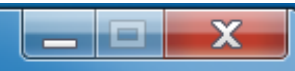

File Computations Misc Help

\begin{tabular}{l|l|l|l|l}
\hline Graphic & Verbal & Matrix & Questionnaire \\
\hline
\end{tabular}

Comparisons wrt "Work travel" node in "Sub-criteria" cluster

Overtime is strongly more important than Number of projects

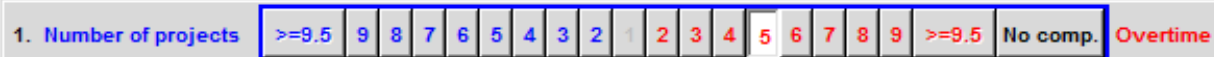

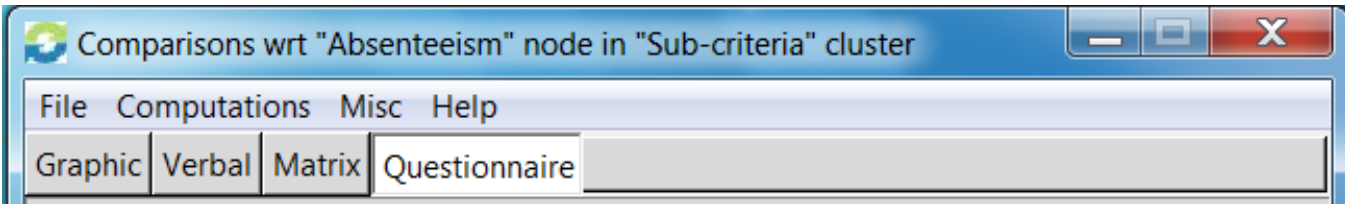

Comparisons wrt "Absenteeism" node in "Sub-criteria" cluster

Overtime is strongly to very strongly more important than Number of projects

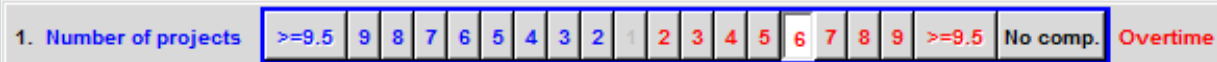

2. Number of projects \begin{tabular}{c|c|c|c|c|c|c|c|c|c|c|c|c|c|c|c|c|c|c|c|}
$s=9.5$ & 9 & 8 & 7 & 6 & 5 & 4 & 3 & 2 & 1 & 2 & 3 & 4 & 5 & 6 & 7 & 8 & 9 & $>=9.5$ & No comp. Work travel
\end{tabular}

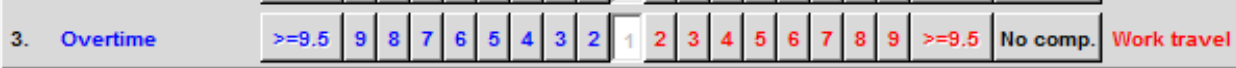

Figure 3. Questionnaire for evaluating dependencies

From each comparison matrix, the local priorities are calculated using the eigenvalue method developed by Saaty (1977):

$$
\mathbf{A} \cdot \mathbf{p}=\lambda \cdot \mathbf{p}
$$


where $\mathbf{A}$ is the comparison matrix; $\mathbf{p}$ is the priorities or weight vector; $\lambda$ is the maximal eigenvalue.

The calculated priorities are entered in the supermatrix. For example in bold, we see the priorities of

Figure 2. These are the weight of the criteria before the dependencies are taken into account.

Table 3: Supermatrix

\begin{tabular}{|c|c|c|c|c|c|c|c|c|c|c|}
\hline & Goal & \multicolumn{6}{|c|}{ Criteria } & \multicolumn{3}{|c|}{ Sub-criteria } \\
\hline & $\begin{array}{l}\text { Employee } \\
\text { performance } \\
\text { evaluation }\end{array}$ & Absenteeism & Felxibility & Initiative & $\begin{array}{l}\text { Self- } \\
\text { development }\end{array}$ & Seniority & $\begin{array}{l}\text { Working } \\
\text { relationship }\end{array}$ & $\begin{array}{l}\text { Number } \\
\text { of } \\
\text { projects }\end{array}$ & Overtime & $\begin{array}{l}\text { Work } \\
\text { travel }\end{array}$ \\
\hline $\begin{array}{l}\text { Employee } \\
\text { performance } \\
\text { evaluation }\end{array}$ & 0 & 0 & 0 & 0 & 0 & 0 & 0 & 0.333 & 0.333 & 0.5 \\
\hline Absenteeism & 0.163 & 0 & 0 & 0 & 0 & 0 & 0 & 0 & 0 & 0 \\
\hline Felxibility & 0.052 & 0.165 & 0 & 0.250 & 0.417 & 0 & 0 & 0 & 0 & 0 \\
\hline Initiative & 0.240 & 0.082 & 0 & 0 & 0.083 & 0 & 0 & 0.333 & 0.333 & 0 \\
\hline $\begin{array}{l}\text { Self- } \\
\text { development }\end{array}$ & 0.027 & 0.174 & 0 & 0.250 & 0 & 0 & 0 & 0 & 0 & 0 \\
\hline Seniority & 0.433 & 0 & 0 & 0 & 0 & 0 & 0 & 0 & 0 & 0 \\
\hline $\begin{array}{l}\text { Working } \\
\text { relationship }\end{array}$ & 0.085 & 0.079 & 0 & 0 & 0 & 0 & 0 & 0 & 0 & 0 \\
\hline $\begin{array}{l}\text { Number of } \\
\text { projects }\end{array}$ & 0 & 0.082 & 0.770 & 0.111 & 0.5 & 0 & 0 & 0 & 0.333 & 0.083 \\
\hline Overtime & 0 & 0.270 & 0.068 & 0.159 & 0 & 0 & 0 & 0 & 0 & 0.417 \\
\hline Work travel & 0 & 0.148 & 0.162 & 0.230 & 0 & 0 & 1 & 0.333 & 0 & 0 \\
\hline
\end{tabular}

The limit matrix is then calculated by squaring the supermatrix many times until the entries have converged. The results are shown in Table 4. In bold, we can see how the weights changed when dependencies are taken into account.

Table 4: Limit matrix

\begin{tabular}{|l|l|l|l|l|l|l|l|l|l|l|}
\hline & \multicolumn{1}{|c|}{ Goal } & \multicolumn{3}{|c|}{ Criteria } & \multicolumn{3}{c|}{ Sub-criteria } \\
\hline & $\begin{array}{l}\text { Employee } \\
\text { performance } \\
\text { evaluation }\end{array}$ & Absenteeism & Felxibility & Initiative & $\begin{array}{l}\text { Self- } \\
\text { development }\end{array}$ & Seniority & $\begin{array}{l}\text { Working } \\
\text { relationship }\end{array}$ & $\begin{array}{l}\text { Number } \\
\text { of } \\
\text { projects }\end{array}$ & $\begin{array}{l}\text { Overtime } \\
\text { Work } \\
\text { travel }\end{array}$ \\
\hline $\begin{array}{l}\text { Employee } \\
\text { performance } \\
\text { evaluation }\end{array}$ & 0.174 & 0.174 & 0.174 & 0.174 & 0.174 & 0 & 0.174 & 0.174 & 0.174 & 0.174 \\
\hline Absenteeism & $\mathbf{0 . 0 3 1}$ & 0.031 & 0.031 & 0.031 & 0.031 & 0 & 0.031 & 0.031 & 0.031 & 0.031 \\
\hline Felxibility & $\mathbf{0 . 0 8 0}$ & 0.080 & 0.080 & 0.080 & 0.080 & 0 & 0.080 & 0.080 & 0.080 & 0.080 \\
\hline Initiative & $\mathbf{0 . 1 5 1}$ & 0.152 & 0.151 & 0.151 & 0.152 & 0 & 0.152 & 0.152 & 0.152 & 0.152 \\
\hline $\begin{array}{l}\text { Self- } \\
\text { development }\end{array}$ & $\mathbf{0 . 0 5 2}$ & 0.052 & 0.052 & 0.052 & 0.052 & 0 & 0.052 & 0.052 & 0.052 & 0.052 \\
\hline Seniority & $\mathbf{0 . 0 8 2}$ & 0.082 & 0.082 & 0.082 & 0.082 & 0 & 0.082 & 0.082 & 0.082 & 0.082 \\
\hline $\begin{array}{l}\text { Working } \\
\text { relationship }\end{array}$ & $\mathbf{0 . 0 1 9}$ & 0.019 & 0.019 & 0.019 & 0.019 & 0 & 0.019 & 0.019 & 0.019 & 0.019 \\
\hline $\begin{array}{l}\text { Number of } \\
\text { projects }\end{array}$ & 0.167 & 0.167 & 0.167 & 0.167 & 0.167 & 0 & 1.167 & 0.167 & 0.167 & 0.167 \\
\hline Overtime & 0.104 & 0.104 & 0.104 & 0 & 0.104 & 0 & 0.104 & 0.104 & 0.104 & 0.104 \\
\hline Work travel & 0.138 & 0.138 & 0.138 & 0 & 0.138 & 0 & 0.138 & 0.138 & 0.138 & 0.138 \\
\hline
\end{tabular}


Finally, the priorities of each cluster are normalised. Initiative is found to be the criterion with the greatest weight. As this organisation falls within the knowledge sector, initiative is an important performance indicator. Seniority is the second most important criterion in this company because the attrition is very high, which is very common in young IT companies. The turnover time is about 2 years. Therefore, the company wants to retain the employees and gave a high weight to this criterion (Pereira et al. 2015). The weight of the sub-criteria must be multiplied by the weight of flexibility (e.g. Nbrs projects $=0.052 \cdot 0.77)$. The weights of the criteria can be found in Table 5 .

Table 5 Weight of the criteria

\begin{tabular}{lcc}
\hline \multicolumn{1}{c}{ Criteria } & Weight \\
\hline Seniority & 0.19709 \\
\hline Initiative & 0.36432 \\
\hline Absenteeism & 0.07410 \\
\hline Working relationship & 0.04531 \\
\hline Flexibility & 0.19336 \\
\hline Self-development & 0.12583 \\
\multicolumn{1}{c}{ Flexibility sub-criteria } & unnormalised \\
& weight & \\
\hline Number of projects & 0.40827 & 0.078943 \\
\hline Work travel & 0.33765 & 0.065288 \\
\hline Overtime & 0.25408 & 0.049129 \\
& & \\
\hline
\end{tabular}

\subsection{Preference functions}

PROMETHEE has six preference functions: usual function, U-shape, V-shape, Level (Figure 5), V-shape, V-shape with indifference (Figure 4), Gaussian (Figure 6). They can be separated into three type as the usual (indifference $=$ preference $=0$ ), the $\mathrm{V}$-shape (indifference $=0$ ) and the U-shape (indifference $=$ preference) are particular cases of the V-shape with indifference (Figure 4). 


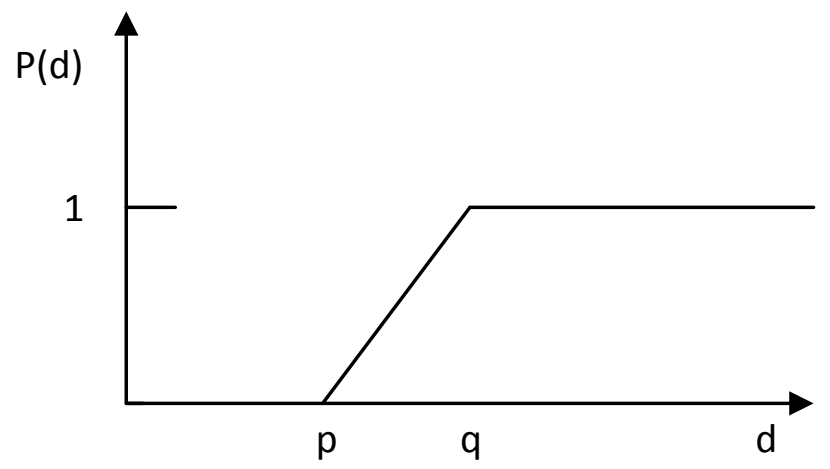

Figure 4: V-shape with indifference preference function

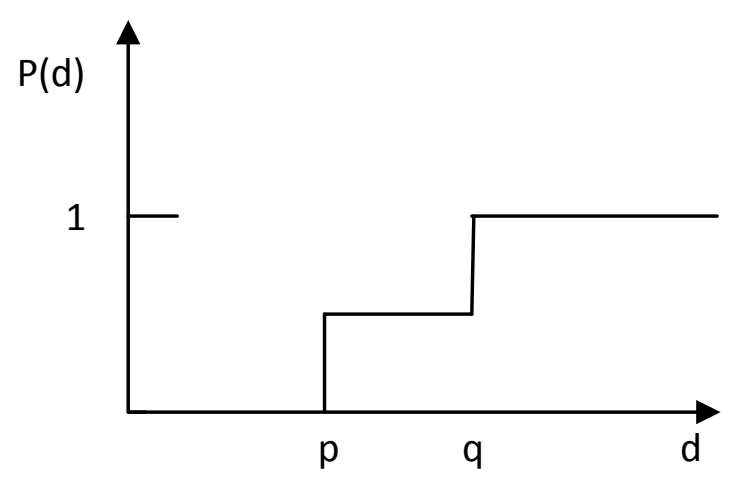

Figure 5: Level preference function

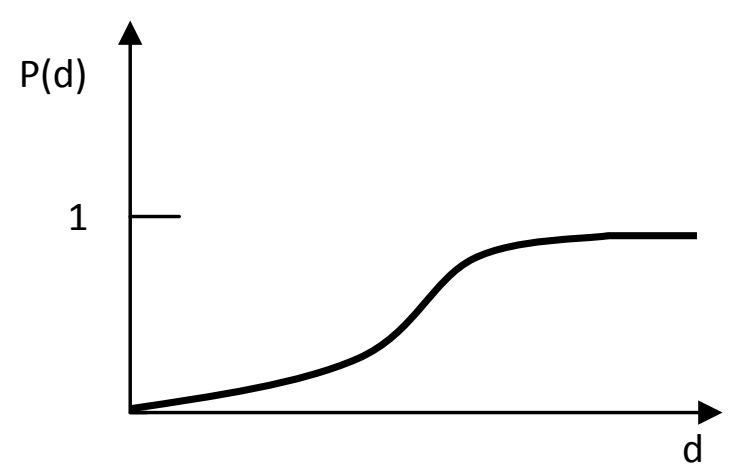

Figure 6: Gaussian preference function

The managers were explained the different preference functions. They decided to opt for a V-shape with indifference preference function because the thresholds were important to avoid overweighting some criteria. We then defined the thresholds in interaction with the mangers. The 
first step is to understand if a threshold exists. If a minimum performance needs to be achieved then an indifference threshold is added. Similarly in order to prevent overemphasising criteria, preferences threshold are also used.

Table 6 Thresholds used in the PROMETHEE model for staff evaluation

\begin{tabular}{|c|c|c|}
\hline Criterion & $\begin{array}{l}\text { Indifference threshold } \\
\text { Preference threshold }\end{array}$ & Explanation \\
\hline \multirow[t]{2}{*}{$\begin{array}{c}\text { Seniority } \\
\text { (year) }\end{array}$} & 2 & $\begin{array}{l}\text { Efficiency of the employee will only be } \\
\text { significant when he has completed two years } \\
\text { in the company. }\end{array}$ \\
\hline & 5 & $\begin{array}{l}\text { The industry has a norm of high turn-over. } \\
\text { Hence, somebody that stays more than } 5 \\
\text { years is perceived to be less efficient and less } \\
\text { in demand in the market and as a } \\
\text { consequence having a low performance. }\end{array}$ \\
\hline \multirow[t]{2}{*}{ Initiative } & 1 & $\begin{array}{l}\text { Initiative is evaluated on a scale 1-10, where } \\
\text { any difference counts. Therefore the } \\
\text { indifference threshold has been set to the } \\
\text { minimum scale. }\end{array}$ \\
\hline & 10 & $\begin{array}{l}\text { Initiative is evaluated on a scale } 1-10 \text {, where } \\
\text { any difference counts. Therefore the } \\
\text { indifference threshold has been set to the } \\
\text { maximum scale. }\end{array}$ \\
\hline \multirow[t]{2}{*}{$\begin{array}{l}\text { Absenteeism } \\
\quad \text { (days) }\end{array}$} & 7 & $\begin{array}{l}\text { It is company rule that up to seven days } \\
\text { absenteeism is acceptable. }\end{array}$ \\
\hline & 10 & $\begin{array}{l}\text { Any absenteeism above } 10 \text { days does not } \\
\text { make any difference because indifferently of } \\
\text { the duration, the employee is called to a } \\
\text { disciplinary procedure. }\end{array}$ \\
\hline Working relationship & 1 & $\begin{array}{l}\text { Working relationship is evaluated on a scale } 1- \\
10, \text { where any difference counts. Therefore } \\
\text { the indifference threshold has been set to the } \\
\text { minimum scale. }\end{array}$ \\
\hline
\end{tabular}




\begin{tabular}{|c|c|c|}
\hline & 10 & $\begin{array}{l}\text { Working relationship is evaluated on a scale 1- } \\
10, \text { where any difference counts. Therefore } \\
\text { the indifference threshold has been set to the } \\
\text { maximum scale. }\end{array}$ \\
\hline \multirow[t]{2}{*}{ Self-development } & 1 & $\begin{array}{l}\text { Self-development is evaluated on a scale } 1- \\
10, \text { where any difference counts. Therefore } \\
\text { the indifference threshold has been set to the } \\
\text { minimum scale. }\end{array}$ \\
\hline & 10 & $\begin{array}{l}\text { Self-development is evaluated on a scale } 1- \\
10, \text { where any difference counts. Therefore } \\
\text { the indifference threshold has been set to the } \\
\text { maximum scale. }\end{array}$ \\
\hline \multirow[t]{2}{*}{ Number of projects } & 1 & $\begin{array}{l}\text { It is expected that at least one project a year } \\
\text { is completed }\end{array}$ \\
\hline & 3 & $\begin{array}{l}\text { More than three projects will overload the } \\
\text { employee's time and will then affect the } \\
\text { quality of work }\end{array}$ \\
\hline \multirow[t]{2}{*}{$\begin{array}{c}\text { Work travel } \\
\text { (days) }\end{array}$} & 7 & $\begin{array}{l}\text { Travels below } 8 \text { working days has an } \\
\text { insignificant impact on the business }\end{array}$ \\
\hline & 30 & $\begin{array}{l}\text { We do not want to have staff that only travel, } \\
\text { therefore the preference threshold is set to } 30 \\
\text { days. }\end{array}$ \\
\hline \multirow[t]{2}{*}{$\begin{array}{l}\text { Overtime } \\
\text { (days) }\end{array}$} & 3 & $\begin{array}{l}\text { Up to three days overtime do not affect the } \\
\text { ranking because it is normal expectation }\end{array}$ \\
\hline & 7 & $\begin{array}{l}\text { Seven days overtime or more days will not } \\
\text { affect the ranking because we do not want } \\
\text { that employee do too many days overtime } \\
\text { and their wok-life balance is affected }\end{array}$ \\
\hline
\end{tabular}

\subsection{Aggregated Preference Functions}

To evaluate the extent to which action $a$ is preferred to $b$ overall in terms of the criteria, the preference index $\pi(a, b)$ is calculated with a weighted sum (4) of the preference degrees $P_{i}(a, b)$. The weights $w_{i}$, calculated previously in section 3.2, represent the importance of each criterion in the decision. 


$$
\pi(a, b)=\sum_{\mathbf{1}=\mathbf{1}}^{\boldsymbol{n}} \boldsymbol{P}_{\boldsymbol{i}}(\boldsymbol{a}, \boldsymbol{b}) \cdot \boldsymbol{w}_{\boldsymbol{i}}
$$

where $P_{i}(a, b)$ is the score of the preference function, $w_{i}$ the weight of criterion $c_{i}$ and $n$ the number of criteria. Table 7 and Table 8 shows the global preference degree for employee A1.

Table 7Global preference degree $\pi(\mathrm{A} 1, \mathrm{x})$, where $\mathrm{x}$ is other employees

\begin{tabular}{|c|c|c|c|c|c|c|c|c|c|}
\hline A1 & A2 & A3 & A4 & A5 & A6 & A7 & A8 & A9 & A10 \\
\hline 0 & 0.05897 & 0.07032 & 0.07536 & 0.0369 & 0.06529 & 0.07032 & 0.14423 & 0.07032 & 0.06529 \\
\hline A11 & $\mathrm{A} 12$ & $\mathrm{~A} 13$ & A14 & A15 & A16 & A17 & A18 & A19 & A20 \\
\hline 0.07032 & 0.06529 & 0.06529 & 0.06529 & 0.22035 & 0.14625 & 0.17987 & 0.16023 & 0.18673 & 0.16023 \\
\hline A21 & A22 & A23 & A24 & A25 & A26 & A27 & A28 & A29 & A30 \\
\hline 0.11584 & 0.0843 & 0.1108 & 0.1703 & 0.11584 & 0.12982 & 0.15128 & 0.11975 & 0.18673 & 0.24521 \\
\hline A31 & A32 & A33 & A34 & A35 & A36 & A37 & A38 & A39 & A40 \\
\hline 0.18673 & 0.16023 & 0.18673 & 0.21972 & 0.21469 & 0.21469 & 0.10577 & 0.16526 & 0.21972 & 0.21469 \\
\hline A41 & A42 & A43 & A44 & A45 & A46 & A47 & A48 & A49 & A50 \\
\hline 0.25416 & 0.21469 & 0.26915 & 0.26423 & 0.26912 & 0.38272 & 0.29888 & 0.31869 & 0.34828 & 0.24119 \\
\hline A51 & A52 & A53 & A54 & A55 & A56 & A57 & A58 & A59 & A60 \\
\hline 0.24622 & 0.20574 & 0.24622 & 0.20574 & 0.24018 & 0.20574 & 0.23727 & 0.23224 & 0.22721 & 0.23224 \\
\hline A61 & A62 & A63 & A64 & A65 & A66 & A67 & A68 & A69 & A70 \\
\hline 0.23727 & 0.2602 & 0.17421 & 0.11975 & 0.18931 & 0.15632 & 0.16526 & 0.1703 & 0.16929 & 0.20003 \\
\hline A71 & A72 & A73 & A74 & A75 & A76 & A77 & A78 & A79 & A80 \\
\hline 0.20895 & 0.17742 & 0.17533 & 0.1438 & 0.09437 & 0.1438 & 0.16526 & 0.1108 & 0.0843 & 0.13876 \\
\hline A81 & A82 & A83 & A84 & A85 & A86 & A87 & A88 & A89 & A90 \\
\hline 0.16526 & 0.22979 & 0.1703 & 0.20394 & 0.19888 & 0.18428 & 0.13485 & 0.22476 & 0.12478 & 0.1438 \\
\hline A91 & A92 & A93 & A94 & A95 & A96 & A97 & A98 & A99 & A100 \\
\hline 0.13485 & 0.18428 & 0.12982 & 0.26825 & 0.20024 & 0.25819 & 0.12478 & 0.13318 & 0.17533 & 0.18428 \\
\hline A101 & A102 & A103 & A104 & A105 & A106 & A107 & A108 & A109 & A110 \\
\hline 0.16526 & 0.22476 & 0.17533 & 0.18428 & 0.16526 & 0.18428 & 0.20473 & 0.25819 & 0.2442 & 0.29866 \\
\hline \multicolumn{10}{|l|}{ A111 } \\
\hline
\end{tabular}


Table 8 Global preference degree $\pi(\mathrm{x}, \mathrm{A} 1)$, where $\mathrm{x}$ is other employees

\begin{tabular}{|c|c|c|c|c|c|c|c|c|c|}
\hline A1 & $A 2$ & A3 & A4 & A5 & A6 & A7 & A8 & A9 & A10 \\
\hline 0 & 0 & 0 & 0 & 0 & 0 & 0 & 0.04913 & 0.04913 & 0.04913 \\
\hline A11 & A12 & A13 & A14 & A15 & A16 & A17 & A18 & A19 & A20 \\
\hline 0.04913 & 0.04913 & 0.04913 & 0.04913 & 0.04913 & 0.04913 & 0.04913 & 0.04913 & 0.04913 & 0 \\
\hline A21 & A22 & A23 & A24 & A25 & A26 & A27 & A28 & A29 & A30 \\
\hline 0 & 0 & 0.04913 & 0.04913 & 0.04913 & 0.04913 & 0.04913 & 0.04913 & 0.04913 & 0.04913 \\
\hline A31 & A32 & A33 & A34 & A35 & A36 & A37 & A38 & A39 & A40 \\
\hline 0.04913 & 0.04913 & 0.04913 & 0 & 0.01228 & 0 & 0.01228 & 0 & 0 & 0 \\
\hline A41 & A42 & A43 & A44 & A45 & A46 & A47 & A48 & A49 & A50 \\
\hline 0.01228 & 0 & 0.02456 & 0 & 0 & 0 & 0.01228 & 0 & 0 & 0 \\
\hline A51 & A52 & A53 & A54 & A55 & A56 & A57 & A58 & A59 & A60 \\
\hline 0 & 0.04913 & 0 & 0.01228 & 0.04913 & 0 & 0.03685 & 0 & 0 & 0.04913 \\
\hline A61 & A62 & A63 & A64 & A65 & A66 & A67 & A68 & A69 & A70 \\
\hline 0 & 0 & 0 & 0 & 0 & 0 & 0 & 0 & 0 & 0 \\
\hline A71 & A72 & A73 & A74 & A75 & A76 & A77 & A78 & A79 & A80 \\
\hline 0 & 0 & 0 & 0 & 0 & 0 & 0.04913 & 0.04913 & 0 & 0 \\
\hline A81 & A82 & A83 & A84 & A85 & A86 & A87 & A88 & A89 & A90 \\
\hline 0 & 0 & 0 & 0 & 0 & 0 & 0 & 0 & 0 & 0 \\
\hline A91 & A92 & A93 & A94 & A95 & A96 & A97 & A98 & A99 & A100 \\
\hline 0 & 0 & 0 & 0 & 0 & 0.01228 & 0 & 0.01228 & 0 & 0.01228 \\
\hline A101 & A102 & A103 & A104 & A105 & A106 & A107 & A108 & A109 & A110 \\
\hline 0.01228 & 0 & 0.01228 & 0 & 0.01228 & 0 & 0.01228 & 0 & 0 & 0 \\
\hline \multicolumn{10}{|l|}{ A111 } \\
\hline 0 & & & & & & & & & \\
\hline
\end{tabular}

\subsection{Outranking flows}

As each action is compared with $m-1$ other actions, two flows can be defined:

Positive flow:

$$
\Phi^{+}(a)=\frac{1}{m-1} \sum_{x \in A}^{m} \pi(a, x)
$$


with $m$ being the number of actions of set $A$. This score represents the global strength of action $a$ in comparison to all the other actions, which needs to be maximised.

Negative flow:

$$
\Phi^{-}(a)=\frac{1}{m-1} \sum_{x \in A}^{m} \pi(x, a)
$$

with $m$ being the number of actions of set $A$. This score represents the global weakness of $a$ in comparison to all the other actions, which needs to be minimised.

In the case of employee A1, introducing the global preference degrees of Table 7 in (2), we optain $\Phi^{+}(A 1)$ $=0.1782$. If we introduce the global preference degrees Table 8 of in $(3)$, we have $\Phi^{-}(A l)=0.0144$.

\subsection{Ranking}

The complete ranking of PROMETHEE II is given by the net flow:

$$
\Phi(a)=\Phi^{+}(a)-\Phi^{-}(a)
$$

For example, the net flow of employee A1 is $\Phi(a)=0.1782-0.0144=0.1638$. The higher the net flows, the better the rank of an action. Table 9 shows the 111 employees of the case study organisation ranked from the best to the worst performing. This is a relative ranking, where the sum of all net scores is 0 . The net score difference between the two extremes is only 0.31408 , which indicates a fairly homogeneous workforce. The managers are the most performing staff with all the nine first positions filled by them. The net scores can be used for reward. Each employee $i$ with a positive net score would be entitled a reward proportional to its score:

$$
\text { Reward }=\frac{\text { Budget for reward }}{\sum_{i=1}^{k} \text { Positive net } \text { score }_{i}} \cdot \text { net }_{\text {score }}
$$

where $\mathrm{k}$ is the number of positive net scores 
Table 9 Net score for each staff member using PROMETHEE

\begin{tabular}{|c|c|c|c|c|c|c|c|c|}
\hline 1 & $\begin{array}{l}\text { A1 - Senior } \\
\text { Manager } 1\end{array}$ & 0.16384 & 38 & $\begin{array}{l}\text { A93 - Part-time } \\
\text { Associate } 8\end{array}$ & 0.01913 & 75 & $\begin{array}{l}\text { A67 - Junior } \\
\text { Associate } 5\end{array}$ & $\begin{array}{l}- \\
0.03073\end{array}$ \\
\hline 2 & $\begin{array}{l}\text { A11 - Assistant } \\
\text { Manager } 4\end{array}$ & 0.12906 & 39 & $\begin{array}{l}\text { A75 - Junior } \\
\text { Associate } 13\end{array}$ & 0.01868 & 76 & $\begin{array}{l}\text { A95 - Deputy } \\
\text { Adminstration } \\
\text { Manager }\end{array}$ & $\begin{array}{l}- \\
0.03128\end{array}$ \\
\hline 3 & $\begin{array}{l}\text { A2 - Senior } \\
\text { Manager } 2\end{array}$ & 0.11435 & 40 & $\begin{array}{l}\text { A80 - Junior } \\
\text { Associate } 18\end{array}$ & 0.01513 & 77 & A65 - Associate 28 & $\begin{array}{l}- \\
0.03337\end{array}$ \\
\hline 4 & $\begin{array}{l}\text { A5 - Shift } \\
\text { Manager } 1 \\
\end{array}$ & 0.11429 & 41 & $\begin{array}{l}\text { A60 - Associate } \\
23\end{array}$ & 0.01366 & 78 & A45 - Associate 8 & $\begin{array}{l}- \\
0.03588\end{array}$ \\
\hline 5 & $\begin{array}{l}\text { A9 - Assistant } \\
\text { Manager } 2\end{array}$ & 0.10898 & 42 & $\begin{array}{l}\text { A33 - Senior } \\
\text { Associate } 6\end{array}$ & 0.01194 & 79 & A51 - Associate 14 & 0.03618 \\
\hline 6 & $\begin{array}{l}\text { A14 - Assistant } \\
\text { Shift Manager } 3\end{array}$ & 0.10456 & 43 & $\begin{array}{l}\text { A97 - Assistant } \\
\text { HR Manager }\end{array}$ & 0.00931 & 80 & A57 - Associate 20 & $\begin{array}{l}-03649 \\
0.03\end{array}$ \\
\hline 7 & $\begin{array}{l}\text { A10 - Assistant } \\
\text { Manager } 3\end{array}$ & 0.10224 & 44 & $\begin{array}{l}\text { A37 - Project } \\
\text { Associate } 4\end{array}$ & 0.00802 & 81 & A42 - Associate 5 & $\begin{array}{l}- \\
0.03872\end{array}$ \\
\hline 8 & $\begin{array}{l}\text { A13 - Assistant } \\
\text { Shift Manager } 2\end{array}$ & 0.10081 & 45 & $\begin{array}{l}\text { A90 - Part-time } \\
\text { Associate } 5\end{array}$ & 0.00761 & 82 & A39 - Associate 2 & $-\overline{0.03896}$ \\
\hline 9 & $\begin{array}{l}\text { A12 - Assistant } \\
\text { Shift Manager } 1\end{array}$ & 0.10043 & 46 & $\begin{array}{l}\text { A72 - Junior } \\
\text { Associate } 10\end{array}$ & 0.00339 & 83 & $\begin{array}{l}\text { A68 - Junior } \\
\text { Associate } 6\end{array}$ & $\begin{array}{l}- \\
0.03931\end{array}$ \\
\hline 10 & $\begin{array}{l}\text { A28 - Senior } \\
\text { Associate } 1\end{array}$ & 0.0884 & 47 & $\begin{array}{l}\text { A91 - Part-time } \\
\text { Associate } 6\end{array}$ & $\begin{array}{l}- \\
0.00135\end{array}$ & 84 & A102 - Clerk 4 & $\begin{array}{l}- \\
0.03953\end{array}$ \\
\hline 11 & $\begin{array}{l}\text { A3 - Deputy } \\
\text { Manager } 1\end{array}$ & 0.0862 & 48 & $\begin{array}{l}\text { A87 - Part-time } \\
\text { Associate } 2\end{array}$ & $\begin{array}{l}- \\
0.00226\end{array}$ & 85 & A54 - Associate 17 & $-\overline{0} 03959$ \\
\hline 12 & $\begin{array}{l}\text { A23 - Principal } \\
\text { Associate } 1\end{array}$ & 0.08491 & 49 & $\begin{array}{l}\text { A20 - Senior B- } \\
\text { Development } \\
\text { Manager }\end{array}$ & $\begin{array}{l}- \\
0.00384\end{array}$ & 86 & $\begin{array}{l}\text { A84 - Junior } \\
\text { Associate } 22\end{array}$ & $\begin{array}{l}- \\
0.04077\end{array}$ \\
\hline 13 & $\begin{array}{l}\text { A7 - Shift } \\
\text { Manager } 3\end{array}$ & 0.077 & 50 & $\begin{array}{l}\text { A89 - Part-time } \\
\text { Associate } 4\end{array}$ & -0.0044 & 87 & A41 - Associate 4 & 0.04082 \\
\hline 14 & $\begin{array}{l}\text { A78 - Junior } \\
\text { Associate } 16\end{array}$ & 0.07091 & 51 & $\begin{array}{l}\text { A76 - Junior } \\
\text { Associate } 14\end{array}$ & $\begin{array}{l}- \\
0.00677\end{array}$ & 88 & A53 - Associate 16 & $\begin{array}{l}- \\
0.04103\end{array}$ \\
\hline 15 & $\begin{array}{l}\text { A4 - Deputy } \\
\text { Manager } 2\end{array}$ & 0.06984 & 52 & $\begin{array}{l}\text { A36 - Project } \\
\text { Associate } 3\end{array}$ & $\begin{array}{l}- \\
0.00754\end{array}$ & 89 & A40 - Associate 3 & -0.0413 \\
\hline 16 & $\begin{array}{l}\text { A8 - Assistant } \\
\text { Manager } 1\end{array}$ & 0.06782 & 53 & $\begin{array}{l}\text { A34 - Project } \\
\text { Associate } 1\end{array}$ & $\begin{array}{l}- \\
0.00768\end{array}$ & 90 & $\begin{array}{l}\text { A69 - Junior } \\
\text { Associate } 7\end{array}$ & $\begin{array}{l}- \\
0.04401\end{array}$ \\
\hline 17 & $\begin{array}{l}\text { A6 - Shift } \\
\text { Manager } 2\end{array}$ & 0.06687 & 54 & $\begin{array}{l}\text { A35 - Project } \\
\text { Associate } 2\end{array}$ & $\begin{array}{l}- \\
0.00836\end{array}$ & 91 & A58 - Associate 21 & $\begin{array}{l}- \\
0.04432\end{array}$ \\
\hline 18 & $\begin{array}{l}\text { A25 - Principal } \\
\text { Associate } 3\end{array}$ & 0.05818 & 55 & A99 - Clerk 1 & -0.0094 & 92 & A59 - Associate 22 & $\begin{array}{l}-04442 \\
0.04\end{array}$ \\
\hline 19 & $\begin{array}{l}\text { A16 - Team } \\
\text { Leader Project } 2\end{array}$ & 0.05363 & 56 & $\begin{array}{l}\text { A63 - Associate } \\
26\end{array}$ & $\begin{array}{l}- \\
0.01053\end{array}$ & 93 & A62 - Associate 25 & $\begin{array}{l}- \\
0.04556\end{array}$ \\
\hline 20 & $\begin{array}{l}\text { A77 - Junior } \\
\text { Associate } 15\end{array}$ & 0.05044 & 57 & $\begin{array}{l}\text { A30 - Senior } \\
\text { Associate } 3\end{array}$ & $\begin{array}{l}- \\
0.01158\end{array}$ & 94 & $\begin{array}{l}\text { A82 - Junior } \\
\text { Associate } 20\end{array}$ & $\begin{array}{l}- \\
0.04721\end{array}$ \\
\hline 21 & A19 - Overall & 0.047 & 58 & A104 - Clerk 6 & - & 95 & A61 - Associate 24 & - \\
\hline
\end{tabular}




\begin{tabular}{|c|c|c|c|c|c|c|c|c|}
\hline & Team Leader & & & & 0.01166 & & & 0.05416 \\
\hline 22 & $\begin{array}{l}\text { A17 - Team } \\
\text { Leader } \\
\text { Coordinator } 1\end{array}$ & 0.04629 & 59 & $\begin{array}{l}\text { A74 - Junior } \\
\text { Associate } 12\end{array}$ & $\begin{array}{l}- \\
0.01328\end{array}$ & 96 & A106 - Clerk 8 & $\begin{array}{l}- \\
0.05479\end{array}$ \\
\hline 23 & $\begin{array}{l}\text { A79 - Junior } \\
\text { Associate } 17\end{array}$ & 0.04623 & 60 & $\begin{array}{l}\text { A55 - Associate } \\
18\end{array}$ & $\begin{array}{l}- \\
0.01367\end{array}$ & 97 & $\begin{array}{l}\text { A88 - Part-time } \\
\text { Associate } 3\end{array}$ & $\begin{array}{l}- \\
0.05877\end{array}$ \\
\hline 24 & $\begin{array}{l}\text { A27 - Training } \\
\text { Principal } \\
\text { Associate }\end{array}$ & 0.04579 & 61 & A38 - Associate 1 & $-\overline{0.01411}$ & 98 & A96 - HR Manager & 0.06112 \\
\hline 25 & $\begin{array}{l}\text { A18 - Team } \\
\text { Leader } \\
\text { Coordinator } 2\end{array}$ & 0.04444 & 62 & A103 - Clerk 5 & -0.0144 & 99 & A47 - Associate 10 & $\begin{array}{l}- \\
0.06504\end{array}$ \\
\hline 26 & $\begin{array}{l}\text { A52 - Associate } \\
15\end{array}$ & 0.0439 & 63 & $\begin{array}{l}\text { A85 - Junior } \\
\text { Associate } 23\end{array}$ & $\begin{array}{l}- \\
0.01642\end{array}$ & 100 & A107 - Clerk 9 & $\begin{array}{l}- \\
0.06616\end{array}$ \\
\hline 27 & $\begin{array}{l}\text { A26 - Principal } \\
\text { Associate } 4\end{array}$ & 0.04387 & 64 & $\begin{array}{l}\text { A56 - Associate } \\
19\end{array}$ & -0.0182 & 101 & $\begin{array}{l}\text { A111 - Personal } \\
\text { Assistant } 2\end{array}$ & $\begin{array}{l}- \\
0.06639\end{array}$ \\
\hline 28 & $\begin{array}{l}\text { A29 - Senior } \\
\text { Associate } 2\end{array}$ & 0.03936 & 65 & $\begin{array}{l}\text { A66 - Associate } \\
29\end{array}$ & $\begin{array}{l}- \\
0.01838\end{array}$ & 102 & $\begin{array}{l}\text { A109 - } \\
\text { Stenographer } 2\end{array}$ & $\begin{array}{l}- \\
0.06991\end{array}$ \\
\hline 29 & $\begin{array}{l}\text { A32 - Senior } \\
\text { Associate } 5\end{array}$ & 0.03855 & 66 & $\begin{array}{l}\text { A81 - Junior } \\
\text { Associate } 19\end{array}$ & $\begin{array}{l}- \\
0.01912\end{array}$ & 103 & $\begin{array}{l}\text { A71 - Junior } \\
\text { Associate } 9\end{array}$ & $\begin{array}{l}- \\
0.07277\end{array}$ \\
\hline 30 & $\begin{array}{l}\text { A21 - Deputy B- } \\
\text { Development } \\
\text { Manager }\end{array}$ & 0.03773 & 67 & $\begin{array}{l}\text { A70 - Junior } \\
\text { Associate } 8\end{array}$ & $-\overline{0.02101}$ & 104 & A44 - Associate 7 & 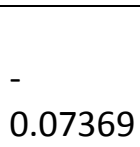 \\
\hline 31 & $\begin{array}{l}\text { A64 - Associate } \\
27\end{array}$ & 0.035 & 68 & $\begin{array}{l}\text { A73 - Junior } \\
\text { Associate } 11\end{array}$ & $\begin{array}{l}- \\
0.02214\end{array}$ & 105 & $\begin{array}{l}\text { A94 - } \\
\text { Adminstration } \\
\text { Manager }\end{array}$ & $\begin{array}{l}- \\
0.07738\end{array}$ \\
\hline 32 & $\begin{array}{l}\text { A24 - Principal } \\
\text { Associate } 2\end{array}$ & 0.0336 & 69 & A105 - Clerk 7 & $\begin{array}{l}- \\
0.02282\end{array}$ & 106 & A43 - Associate 6 & $\begin{array}{l}- \\
0.07902\end{array}$ \\
\hline 33 & $\begin{array}{l}\text { A98 - Marketing } \\
\text { Manager }\end{array}$ & 0.03064 & 70 & A101 - Clerk 3 & $\begin{array}{l}- \\
0.02322\end{array}$ & 107 & $\begin{array}{l}\text { A110 - Personal } \\
\text { Assiatant } 1\end{array}$ & $\begin{array}{l}- \\
0.09057\end{array}$ \\
\hline 34 & $\begin{array}{l}\text { A31 - Senior } \\
\text { Associate } 4\end{array}$ & 0.02619 & 71 & $\begin{array}{l}\text { A92 - Part-time } \\
\text { Associate } 7\end{array}$ & $\begin{array}{l}- \\
0.02467\end{array}$ & 108 & $\begin{array}{l}\text { A108 - } \\
\text { Stenographer } 1\end{array}$ & $\begin{array}{l}- \\
0.09314\end{array}$ \\
\hline 35 & $\begin{array}{l}\text { A15 - Team } \\
\text { Leader Project } 1\end{array}$ & 0.02547 & 72 & $\begin{array}{l}\text { A86 - Part-time } \\
\text { Associate } 1\end{array}$ & $\begin{array}{l}- \\
0.02693 \\
\end{array}$ & 109 & A49 - Associate 12 & $\begin{array}{l}- \\
0.10226\end{array}$ \\
\hline 36 & A22 - IT Manager & 0.02396 & 73 & $\begin{array}{l}\text { A83 - Junior } \\
\text { Associate } 21\end{array}$ & $\begin{array}{l}- \\
0.02736\end{array}$ & 110 & A48 - Associate 11 & $\begin{array}{l}- \\
0.11665\end{array}$ \\
\hline 37 & A100 - Clerk 2 & 0.0228 & 74 & $\begin{array}{l}\text { A50 - Associate } \\
13\end{array}$ & $\begin{array}{l}- \\
0.02786\end{array}$ & 111 & A46 - Associate 9 & $\begin{array}{l}-15024 \\
0.150\end{array}$ \\
\hline
\end{tabular}

Figure 7 illustrates the GAIA plane. It portrays the full picture by representing all the employees on

the same graph. This allows us to compare employees and at the same time helps to discover clusters. The findings show that the majority of the employees are in the middle left of the GAIA plane. The best performing employees are on right of the plane: they complete many projects, work several overtime hours, have a good working relationship and develop themselves. At the top left, Assistant Manager 1, 
Senior associate 3 and Associate 18 opt for and undertake work travel are not often absent but undertake few projects, which affects their performance score. Based on these results, it may be worth the organisation investigating the fact that their travel duty hinders them to undertake several projects and also to propose a solution as a remedying measure. All employees on the right of the Figure 7 are doing a lot of overtime, have a good working relationship and a high self-development. Employee 95, 96, 107. $108,109,110$ and 111 are in a cluster of particularly weak on the number of projects they undertake. Employee 8 is also weak on number of projects but (s)he strong in in other area (overtime, work relationship and self-development).
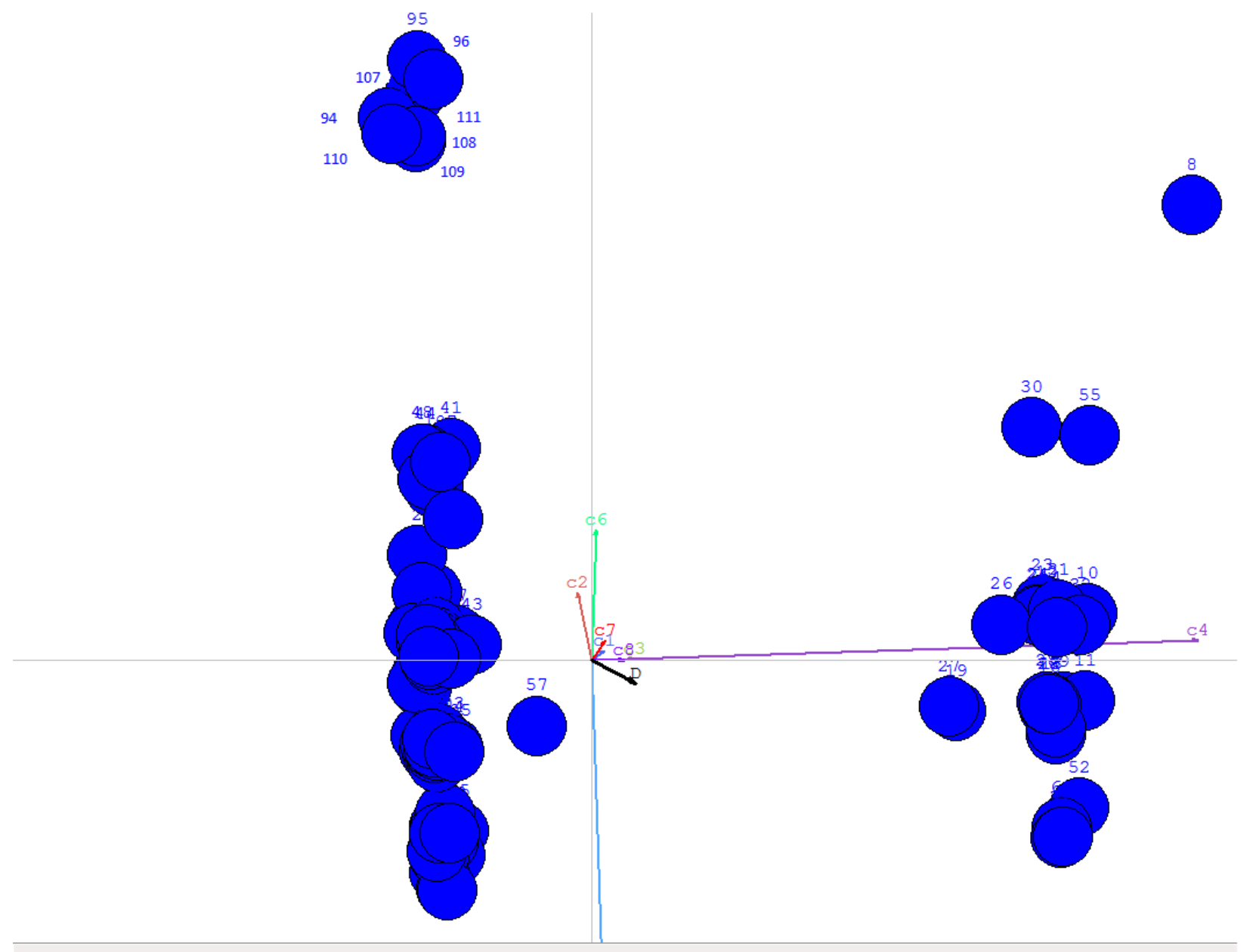

Figure 7. GAIA plane of the 111 employees (projection reliability $\delta=77 \%$ ) 
Figure 8 focuses on the centre of the GAIA plane in Figure 7. It indicates that overtime and number of projects are the two criteria that have the best discriminating power for evaluating employees because they have long arrows. The criterion seniority has a low discriminating power (short arrow), which indicates that the employees of this company have almost the same seniority. As the arrows for working relationship, overtime and self-development are pointing in the same direction, this indicates that these criteria are correlated: employees are good (performing) or bad (not performing) simultaneously on the three criteria. The arrow for number of projects is $180^{\circ}$ the opposite of work travel and absenteeism, indicating that the employees who accomplish projects do not travel but have a high absenteeism rate and vice versa. These employees also have low initiative (arrow c7). 


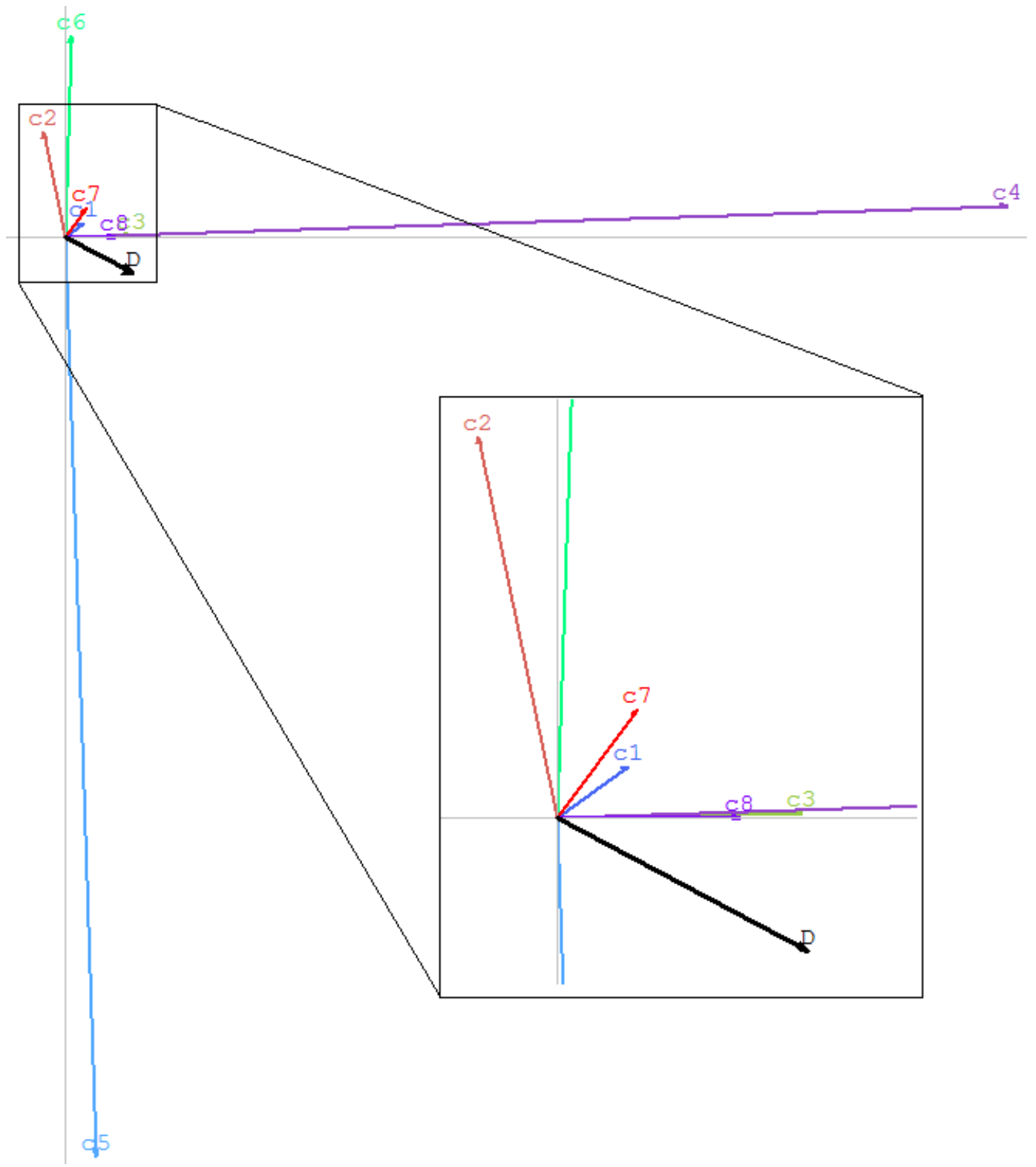
C1: Seniority
C2: Absenteism
C3: Working relationship
C4: Overtime
C5: Number of projects
C6: Work travel
C7: Initiative
C8: Self-develpment

Figure 8. Discriminating power of criteria

On the Figure 9, employees are ranked in a decreasing order according to their net score (sum of positive and negative). This ranking is the same than on Table 9. Moreover, Figure 9 shows a stacked bar 
chart of the contribution of each evaluation criterion to the global score. Gamma's management can now identify the strengths (that could be used for promotion) and weaknesses (that can be used for training and development) of each employee. A negative score means that they are below average. For example, employees A8 would be the best employee if they could improve on the number of projects they complete. As already seen on the GAIA plane, Employees A94, A95, A96, A107, A108, A110 and A111 are low in the number of projects they take, which ranks them at the bottom of the evaluation scale.

Several employees have a very small bar, which indicates that they need to improve on all six evaluation criteria.
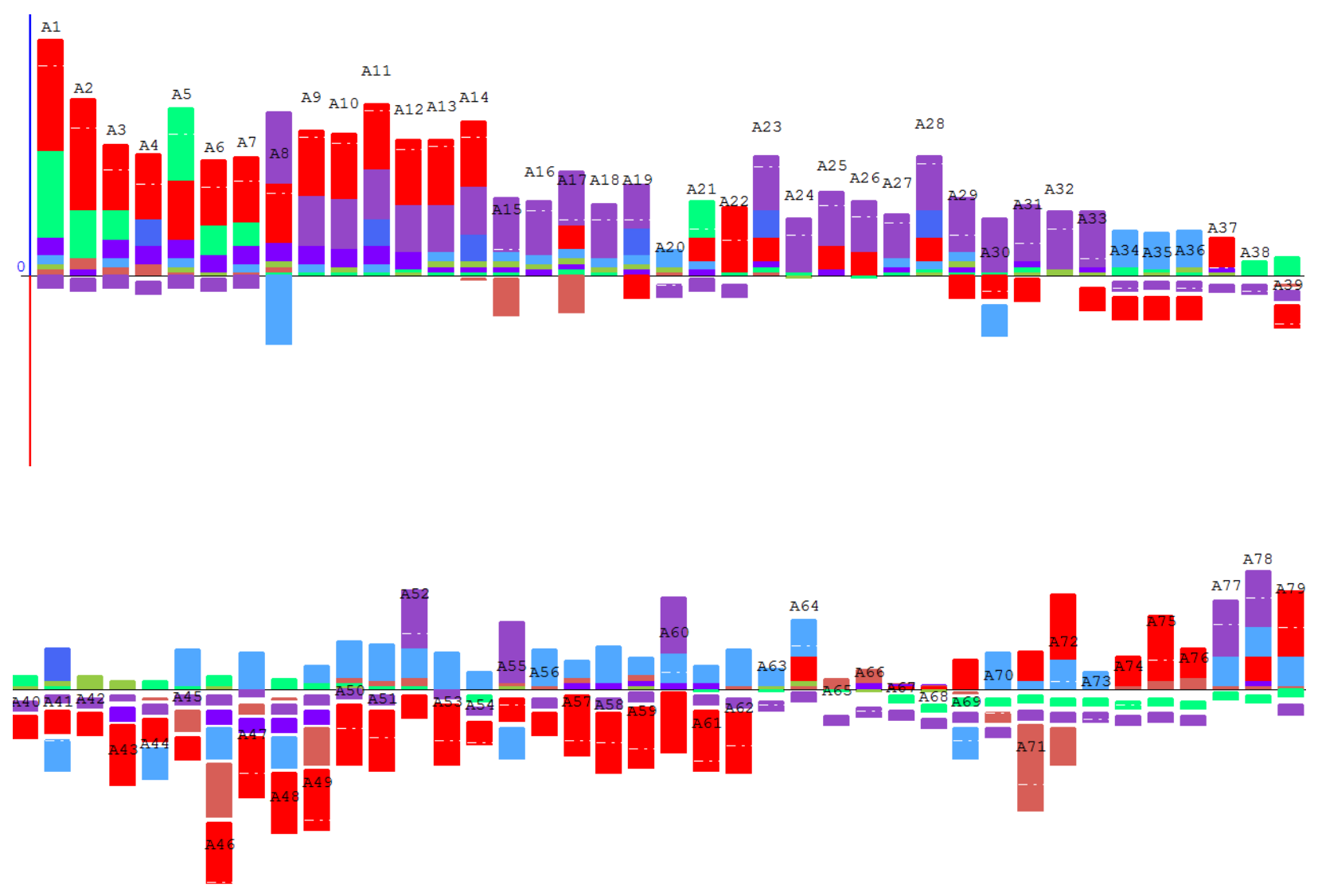


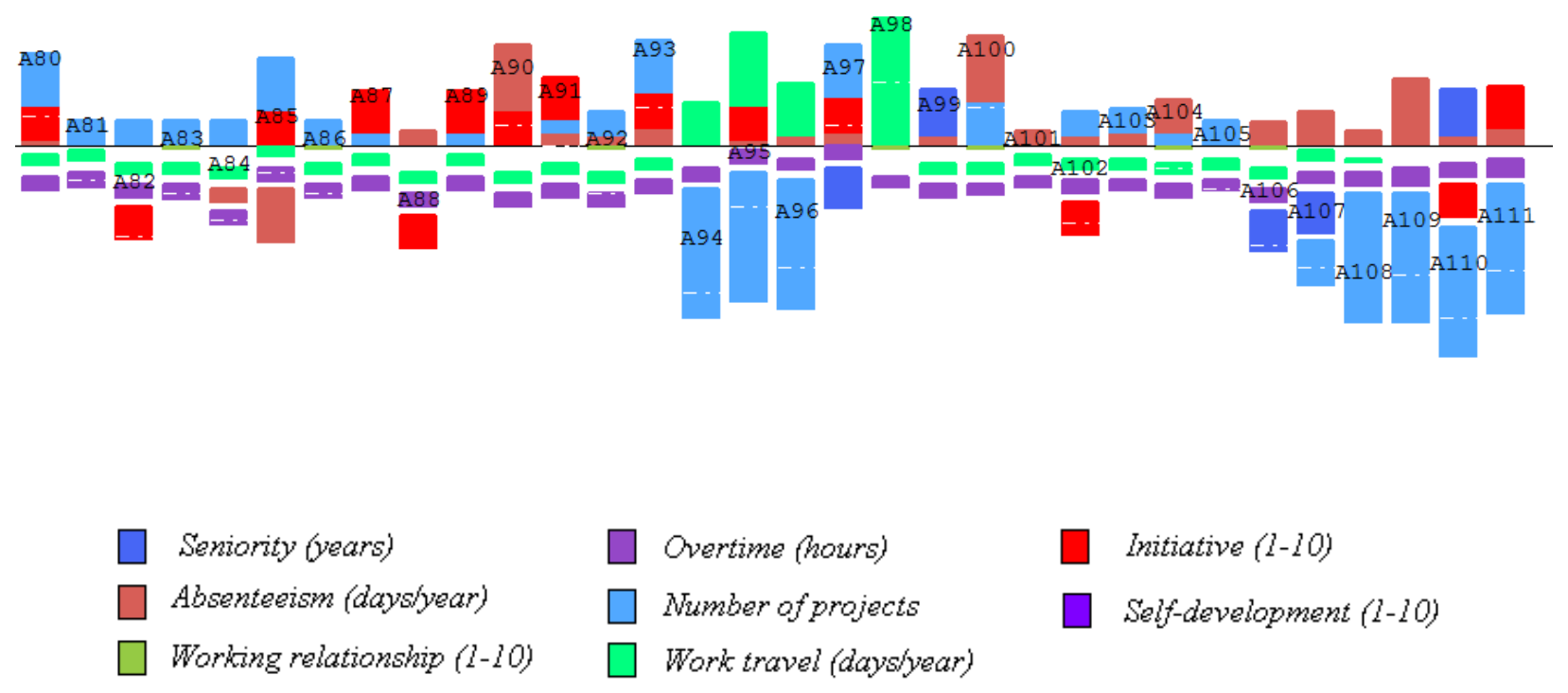

Figure 9. Stacked bar chart of employee performance

\section{Conclusions}

Every organisation assesses the performance of its employees. However, when appraisal is perceived as an ineffective and complex formality comprising form filling, its benefits diminish. This paper has introduced trans-disciplinary methods from operational research in the form of multi-criteria decision analysis (MCDA) and visual techniques to develop a transparent, structured, and honest employee performance management method. The multi-criteria analysis transparently combines qualitative and quantitative decision criteria into a holistic evaluation. The visual techniques allow the organisation to gain a deep insight into their employees' skills profiles structures and captures finer details in relation to where individuals are performing or underperforming. For the manager, this evaluation is easier to communicate because visual tools are conceptually easier to understand than a set of scores. The feedback on improvement measures can be precisely formulated. They may include developmental activities (e.g. training) to rectify performance deficiencies. The evaluation method can also be used for promotion or 
rewards. The evaluations are fully retraceable and therefore justifiable, which ensures the fairness of the decision, enhancing the trust and potentially the productivity of the employees.

PROMETHEE is a partial compensatory method, which means that bad scores cannot be compensated by good scores. Indifference thresholds define the minimum necessary for each criterion to be achieved in order to start to accumulate a positive flow. The preference threshold is on the other end the maximum allowed to be accumulated in the positive flow. This permits to avoid employee to strategically concentrate on only the measured criteria. However, it is to note that there is not an overall fitting model. The criteria and their weighting depend on the vision and strategy of the management, which are by definition subjective. Visual techniques provide more information than a simple ranking. For example, in our case study, we have identified three different categories of employees on the GAIA plane. As an example, a correlation between work travel and absenteeism is highlighted. Moreover the stacked bar chart indicates where poor performance on one criterion can be totally compensated and masked by others.

In terms of future research, a further development of this work would be to develop an interactive visualisation tool to assess the sensitivity of an action when performances are varied. For example, we can test if an employee would improve the criterion XX by $10 \%$, then he will be among the top 20 employees and he will receive a higher reward. This will motivate an employee to know in advance the benefits of an improvement. Another research direction would be to apply the MCDA and visual techniques to other areas, such as environmental or quality analysis. 


\section{References}

Aguinis, H., Joo, H. and Gottfredson, R. (2011) 'Why we hate performance management-And why we should love it', Business Horizons, 54(6), 503-507.

Alcaraz, J., Domènech, M. and Tirado, F. (2012) 'eHR software, multinational corporations and emerging China: Exploring the role of information through a postcolonial lens', Information and Organization, 22(2), 106-124.

Alferoff, C. and Knights, D. (2008) 'Customer relationship management in call centers: The uneasy process of re(form)ing the subject through the 'people-by-numbers' approach', Information and Organization, 18(1), 29-50.

Amaratunga, D. and Baldry, D. (2002) 'Moving from performace measurement to performance management', Facilities, 20(5/6), 217-223.

Armstrong, M. and Taylor, S. (2014) Armstrong's Handbook of Human Resource Management Practice, London: Kogan Page Publishers.

Barrick, M. and Mount, M. (1991) 'The big five personality dimensions and job performance: a metaanalysis', Personnel Psychology, 44(1), 1-26.

Beausaert, S., Segers, M. and Gijselaers, W. (2011) 'Using a personal development plan for different purposes: its influence on undertaking learning activities and job performance', Vocations and Learning, 4(3), 231-252.

Behzadian, M., Kazemzadeh, R. B., Albadvi, A. and Aghdasi, M. (2010) 'PROMETHEE: A comprehensive literature review on methodologies and applications', European Journal of Operational Research, 200(1), 198-215.

Behzadian, M., Khanmohammadi Otaghsara, S., Yazdani, M. and Ignatius, J. (2012) 'A state-of the-art survey of TOPSIS applications', Expert Systems with Applications, 39(17), 13051-13069.

Bentes, A., Carneiro, J., da Silva, J. and Kimura, H. (2012) 'Multidimensional assessment of organizational performance: Integrating BSC and AHP', Journal of Business Research, 65(12), 1790-1799.

Biron, M., Farndale, E. and Paauwe, J. (2011) 'Performance management effectiveness: lessons from world-leading firms', The International Journal of Human Resource Management, 22(6), 12941311. 
Bogdanovic, D., Nikolic, D. and Ilic, I. (2012) 'Mining method selection by integrated AHP and PROMETHEE method', Anais da Academia Brasileira de Ciências, 84(1), 219-233.

Borman, W. (1991) 'Job behavior, performance, and effectiveness' in Dunnette, M., Hough, L. and Triandis, H., eds., Handbook of industrial and organizational psychology Newbury Park: Sage, 271-326.

Bozbura, F., Beskese, A. and Kahraman, C. (2007) 'Prioritization of human capital measurement indicators using fuzzy AHP', Expert Systems with Applications, 32(4), 1100-1112.

Brans, J.-P. (1982) 'L'ingénierie de la décision: Elaboration d'instruments d'aide à la décision' in Nadeaeu, R. and Landry, M., eds., L'aide à la décision: Nature, Instruments et Perspectives d'Avenir, Québec: Presse de l'Université de Laval, 183-213.

Brans, J.-P. and Mareschal, B. (1994) 'The PROMCALC \& GAIA decision support system for multicriteria decision aid', Decision Support Systems, 12(4-5), 297-310.

Brans, J.-P. and Vincke, P. (1985) 'A preference ranking organisation method', Management science, 31(6), 647-656.

Brown, M., Hyatt, D. and Benson, J. (2008) 'Consequences of the performance appraisal experience', Personnel Review, 39(3), 375-396.

Brucker, K., Verbeke, A. and Macharis, C. (2004) 'The applicability of multicriteria-analysis to the evaluation of intelligent transport systems', Research in Transportation Economics, 8(0), 151179.

Chen, A., Lam, W. and Zhong, J. (2007) 'Leader-member exchange and member performance: a new look at individual-level negative feedback-seeking behavior and team-level empowerment climate', Journal of Applied Psychology, 92(1), 202-212.

Cho, Y. and Lee, J. (2012) 'Performance Management and Trust in Supervisors', Review of Public Personnel Administration, 32(3), 236-259.

Coff, R. (1997) 'Human assets and management dilemmas: coping with hazards on the road to resourcebased theory', The Academy of Management Review, 22(2), 374-402. 
Colquitt, J., Scott, B. and Le Pine, J. (2007) 'Trust, trustworthiness, and trust propensity: A meta-analytic test of their unique relationships with risk taking and job performance', Journal of Applied Psychology, 92(4), 909-927.

D'Mello, M. and Eriksen, T. (2010) 'Software, sports day and sheera: Culture and identity processes within a global software organization in India', Information and Organization, 20(2), 81-110.

De Keyser, W. and Peeters, P. (1996) 'A Note on the Use of PROMETHEE Multicriteria Methods', European Journal of Operational Research 89(3), 457-461.

de Waal, A. (2010) 'Performance-driven behavior as the key to improved organizational performance', Measuring Business Excellence, 14(1), 79 - 95.

Eckert, R., Ekelund, B., Gentry, W. and Dawson, J. (2009) '“I don't see me like you see me, but is that a problem?" Cultural influences on rating discrepancy in 360-degree feedback instruments', European Journal of Work and Organizational Psychology, 19(3), 259-278.

Eisenhardt, K. (1985) 'Control: Organizational and economic approaches', Management Science, 31(2), 134-149.

Ensslin, L., Dutra, A. and Ensslin, S. (2000) 'MCDA: a constructivist approach to the management of human resources at a governmental agency', International Transactions in Operational Research, 7(1), 79-100.

Fletcher, C. (2008) Appraisal, feedback and development: Managing performance review at work, 4th ed., Oxford: Routledge.

Forman, E. and Gass, S. (2001) 'The Analytic Hierarchy Process - An Exposition', Operations Research, 49(4), 469-486.

Frezatti, F., Aguiar, A., Guerreiro, R. and Gouvea, M. (2011) 'Does management accounting play role in planning process?', Journal of Business Research, 64(3), 242-249.

Gervásio, H. and Simões da Silva, L. (2012) 'A probabilistic decision-making approach for the sustainable assessment of infrastructures', Expert Systems with Applications, 39(8), 7121-7131.

Gilliams, S., Raymaekers, D., Muys, B. and Van Orshoven, J. (2005) 'Comparing multiple criteria decision methods to extend a geographical information system on afforestation', Computers and Electronics in Agriculture, 49(1), 142-158. 
Govindan, K., Kannan, D. and Shankar, M. (2014) 'Evaluation of green manufacturing practices using a hybrid MCDM model combining DANP with PROMETHEE', International Journal of Production Research, 53(21), 6344-6371.

Gruman, J. and Saks, A. (2011) 'Performance management and employee engagement', Human Resource Management Review, 21(2), 123-136.

Guion, R. M. (1991) 'Personnel assessment, selection, and placement' in Dunnette, M., Hough, L. and Triandis, H., eds., Handbook of industrial and organizational psychology Newbury Park: Sage, 271-326.

Hamzeh, M., Ali Abbaspour, R. and Davalou, R. (2015) 'Raster-based outranking method: a new approach for municipal solid waste landfill (MSW) siting', Environmental Science and Pollution Research, 22(16), 12511-12524.

Heathfield, S. (2007) 'Performance appraisals don't work - What does? ', Journal for Quality \& Participation, 30(1), 6-9.

Herva, M. and Roca, E. (2013) 'Ranking municipal solid waste treatment alternatives based on ecological footprint and multi-criteria analysis', Ecological Indicators, 25(0), 77-84.

Ho, W. (2008) 'Integrated analytic hierarchy process and its applications - A literature review', European Journal of Operational Research, 186(1), 211-228.

Ishizaka, A. and Nemery, P. (2011) 'Selecting the best statistical distribution with PROMETHEE and GAIA', Computers \& Industrial Engineering, 61(4), 958-969.

Ishizaka, A. and Nemery, P. (2013) Multi-Criteria Decision Analysis, Chichester (United Kingdom): John Wiley \& Sons Inc.

Kabak, M. and Dağdeviren, M. (2014) 'A hybrid MCDM approach to assess the sustainability of students' preferences for university selection', Technological and Economic Development of Economy, 20(3), 391-418.

Kerr, J. (1985) 'Diversification strategies and managerial rewards: An empirical study', Academy of Management Journal, 28(1), 155-179. 
Kilic, H., Zaim, S. and Delen, D. (2015) 'Selecting "The Best" ERP system for SMEs using a combination of ANP and PROMETHEE methods', Expert Systems with Applications, 42(5), 2343-2352.

Kumar, S. and Vaidya, O. (2006) 'Analytic hierarchy process: An overview of applications', European Journal of Operational Research 169(1), 1-29.

Kuvaas, B. (2011) 'The interactive role of performance appraisal reactions and regular feedback', Journal of Managerial Psychology, 26(2), 123-137.

Landy, F. and Farr, J. (1980) 'Performance Rating', Psychological Bulletin, 87(1), 72-107.

Law, D. (2007) 'Appraising performance appraisals: a critical look at an external control management techniques', International Journal of Reality Therapy, XXVI(2), 18 - 25.

Liberatore, M. and Nydick, R. (2008) 'The analytic hierarchy process in medical and health care decision making: A literature review', European Journal of Operational Research, 189(1), 194-207.

Liu, Y., Combs, J., Ketchen Jr, D. and Ireland, D. (2007) 'The value of human resource management for organizational performance', Business Horizons, 50(6), 503-511.

Locke, E. and Latham, G. (2006) 'New directions in goal-setting theory', Current Directions in Psychological Science, 15(5), 265-268.

Locke, E., Shaw, K., Saari, L. and Latham, G. (1981) 'Goal setting and task performance: 1969-1980', Psychological Bulletin, 90(1), 125-152

Macharis, C., Springael, J., De Brucker, K. and Verbeke, A. (2004) 'PROMETHEE and AHP: The design of operational synergies in multicriteria analysis.: Strengthening PROMETHEE with ideas of AHP', European Journal of Operational Research, 153(2), 307-317.

Manoharan, T., Muralidharan, C. and Deshmukh, S. (2011) 'An integrated fuzzy multi-attribute decisionmaking model for employees' performance appraisal', The International Journal of Human Resource Management, 22(3), 722-745.

Mareschal, B., De Smet, Y. and Nemery, P. (2008) 'Rank Reversal in the PROMETHEE II Method : Some New Results', in IEEE 2008 International Conference on Industrial Engineering and Engineering Management, Singapore, 
McCarthy, A. and Garavan, T. (1999) 'Developing self-awareness in the managerial career development process: the value of 360-degree feedback and the MBTI', Journal of European Industrial Training, 23(9), 437-445.

McCarthy, A. and Garavan, T. (2001) ' $360^{\circ}$ feedback process: performance, improvement and employee career development', Journal of European Industrial Training, 25(1), 5-32.

Merritt, D. (2007) 'Appraising the performance appraisal', Supervision, 68(4), 3-5.

Millet, I. (1997) 'The effectiveness of alternative preference elicitation methods in the Analytic Hierarchy Process', Journal of Multi-Criteria Decision Analysis, 6(1), 41-51.

Narcisse, S. and Harcourt, M. (2008) 'Employee fairness perceptions of performance appraisal: a Saint Lucian case study', The International Journal of Human Resource Management, 19(6), 11521169.

Nemery, P., Ishizaka, A., Camargo, M. and Morel, L. (2012) 'Enriching descriptive information in ranking and sorting problems with visualizations techniques', Journal of Modelling in Management, 7(2), 130-147.

$\mathrm{Ng}, \mathrm{T}$. and Feldman, D. (2010) 'Organizational tenure and job performance', Journal of Management, $36(5), 1220-1250$.

Obisi, C. (2011) 'Employee performance appraisal and its implication for individual and organizational growth', Australian Journal of Business and Management Research, 1(9), 92-97.

Omkarprasad, V. and Sushil, K. (2006) 'Analytic hierarchy process: an overview of applications', European Journal of Operational Research, 169(1), 1-29.

Organ, D. (1988) Organizational citizenship behavior: The good soldier syndrome, England: Lexington.

Peng, A.-H. and Xiao, X.-M. (2013) 'Material selection using PROMETHEE combined with analytic network process under hybrid environment', Materials \& Design, 47, 643-652.

Pereira, V., Malik, A. and Sharma, K. (2015) 'Colliding employer-employee perspectives of employee turnover: evidence from a born-global industry', Thunderbird International Business Review, advance online publication: DOI: 10.1002/tie.21751, n/a-n/a. 
Pettijohn, L., Parker, S., Pettijohn, C. and Kent, J. (2001) 'Performance appraisals: usage, criteria and observations', Journal of Management Development, 20(9), 754 - 771.

Prowse, P. and Prowse, J. (2009) 'The dilemma of performance appraisal', Measuring Business Excellence, 13(4), 69-77.

Rai, H. and Singh, M. (2013) 'A study of mediating variables of the relationship between $360^{\circ}$ feedback and employee performance', Human Resource Development International, 16(1), 56-73.

Reinke, S. (2003) 'Does the form really matter?: Leadership, trust, and acceptance of the performance appraisal process', Review of Public Personnel Administration, 23(1), 23-37.

Rotundo, M. and Sackett, P. (2002) 'The relative importance of task, citizenship, and counterproductive performance to global ratings of job performance: A policy-capturing approach.', Journal of Applied Psychology, 87(1), 66-80.

Saaty, T. (1977) 'A scaling method for priorities in hierarchical structures', Journal of Mathematical Psychology, 15(3), 234-281.

Saaty, T. (2001) The Analytic Network Process, Pittsburgh: RWS Publications.

Saaty, T., Peniwati, K. and Shang, J. (2007) 'The analytic hierarchy process and human resource allocation: Half the story', Mathematical and Computer Modelling, 46(7-8), 1041-1053.

Salanova, M., Agut, S. and Peiró, J. (2005) 'Linking organizational resources and work engagement to employee performance and customer loyalty: the mediation of service climate', Journal of Applied Psychology, 90(6), 1217-1227.

Sania Zaheer, A. (2011) 'Absence of procedural justice leads to retaliation behaviour', International Journal of Business Research, 11(4), 149-159.

Schweitzer, M., Ordóñez, L. and Douma, B. (2004) 'Goal setting as a motivator of unethical behavior', Academy of Management Journal, 47(3), 422-432.

Selvarajan, T. and Cloninger, P. (2012) 'Can performance appraisals motivate employees to improve performance? A Mexican study ', The International Journal of Human Resource Management, 23(15), 3063-3084. 
Sipahi, S. and Timor, M. (2010) 'The analytic hierarchy process and analytic network process: an overview of applications', Management Decision, 48(5), 775-808.

Skule, S. (2004) 'Learning conditions at work: a framework to understand and assess informal learning in the workplace', International Journal of Training and Development, 8(1), 8-20.

Snell, S. (1992) 'Control theory in strategic human resource management: The mediating effect of administrative information', Academy of Management Journal, 35(2), 292-327.

Snell, S. and Youndt, M. (1995) 'Human Resource Management and Firm Performance: Testing a Contingency Model of Executive Controls', Journal of Management, 21(4), 711-737.

Stansfield, T. and Longenecker, C. (2006) 'The effects of goal setting and feedback on manufacturing productivity: a field experiment', International Journal of Productivity and Performance Managemen, 55(3-4), 346-358.

Tett, R. and Burnett, D. (2003) 'A personality trait-based interactionist model of job performance', Journal of Applied Psychology, 88(3), 500-517.

Tofallis, C. (2008) 'Selecting the best statistical distribution using multiple criteria', Computers \& Industrial Engineering, 54(3), 690-694.

Turcksin, L., Bernardini, A. and Macharis, C. (2011) 'A combined AHP-PROMETHEE approach for selecting the most appropriate policy scenario to stimulate a clean vehicle fleet', Procedia-Social and Behavioral Sciences, 20(0), 954-965.

Ubeda, C. and Santos, F. (2007) 'Staff development and performance appraisal in a Brazilian research centre', European Journal of Innovation Management, 10(1), 109-125.

Vaiman, V. and Vance, C. (2008) Smart Talent Management: Building Knowledge Assets for Competitive Advantage, Cheltenham: Edward Elgar.

Venkata Rao, R. and Patel, B. (2010) 'Decision making in the manufacturing environment using an improved PROMETHEE method', International Journal of Production Research, 48(16), 4665 4682.

Venkatesan, P. and Kumanan, S. (2012) 'Supply chain risk prioritisation using a hybrid AHP and PROMETHEE approach', International Journal of Services and Operations Management, 13(1), 19 $-41$. 
Wang, J.-J. and Yang, D.-L. (2007) 'Using a hybrid multi-criteria decision aid method for information systems outsourcing', Computers and Operations Research, 34(12), 3691-3700.

Wang, Y. and Luo, Y. (2009) 'On Rank Reversal in Decision Analysis', Mathematical and Computer Modelling, 49(5-6), 1221-1229.

Watson Wyatt Worldwide (2004) WorkUSA ${ }^{\circledR} 2004$ : An Ongoing Study of Employee Attitudes and Opinions.

Whitaker, R. (2007) 'Validation examples of the Analytic Hierarchy Process and Analytic Network Process', Mathematical and Computer Modelling, 46(7-8), 840-859.

Williams, S. and Adam-Smith, D. (2010) Contemporary employment relations: a critical introduction, 2nd ed., Oxford: Oxford University Press

Wood, R. and Marshall, V. (2008) 'Accuracy and effectiveness in appraisal outcomes: the influence of self-efficacy, personal factors and organisational variables', Human Resource Management Journal, 18(3), 295-313.

Workman, M. (2009) 'A field study of corporate employee monitoring: Attitudes, absenteeism, and the moderating influences of procedural justice perceptions', Information and Organization, 19(4), 218-232.

Yang, L. and Deuse, J. (2012) 'Multiple-attribute decision making for an energy efficient facility layout design', Procedia CIRP, 3(0), 149-154. 